\title{
Differentiation of Wines Obtained in the Region of Dealurile Moldovei Vineyard Using Multielement Composition - Comparison with Vineyard Soil
}

\author{
Florin Dumitru BORA¹, Anamaria CĂLUGĂR ${ }^{2}$, Claudiu Ioan BUNEA², Vasile Răzvan FILIMON³ \\ ${ }^{1}$ Department of Physico-Chemistry and Biochemistry, Research Station for Viticulture and Oenology Târgu Bujoru, \\ Romania \\ ${ }^{2}$ Department of Horticulture and Landscaping, University of Agricultural Sciences and Veterinary Medicine, Cluj- \\ Napoca, Romania \\ ${ }^{3}$ Department of Vinification, Research Station for Viticulture and Oenology Iași, Romania \\ *Corresponding author: Claudiu Ioan BUNEA e-mail: claus_bunea@yahoo.com
}

RESEARCH ARTICLE

\begin{abstract}
The present study is focused on the determination of mineral composition of international red wines (Merlot, Cabernet Sauvignon), white wines (Sauvignon blanc, Aligoté, Muscat Ottonel, Italian Riesling) and native red wines (Feteasca neagră, Burgund mare, Băbeasca neagră), white wines (Feteasca regală, Fetească albă, Băbeasca gri, Șarba) produced in the Dealu Bujorului vineyard between 2014-2018, using Inductively Coupled Plasma Mass-Spectrometry (ICP-MS), and comparison of mineral composition of the soil. The high level of $\mathrm{Ca}, \mathrm{K}, \mathrm{Na}, \mathrm{Mg}$, $\mathrm{P}$ and $\mathrm{Fe}$ was observed in analyzed wine samples, the concentration of $\mathrm{Na}, \mathrm{Cu}, \mathrm{As}, \mathrm{Cd}, \mathrm{Zn}$ and $\mathrm{Pb}$ metals in analyzed wine samples were under Maximal Permissible Limit. The average concentrations of elements in the soil decrease in the following order: $\mathrm{K}, \mathrm{Na}, \mathrm{Ca}, \mathrm{Cu}, \mathrm{Fe}, \mathrm{P}, \mathrm{Mg}, \mathrm{Li}, \mathrm{Co}, \mathrm{Mn}, \mathrm{Zn}, \mathrm{Pb}, \mathrm{Cr}, \mathrm{As}, \mathrm{U}, \mathrm{Cd}$ and $\mathrm{Hg}$. Cu concentration in the topsoil of the Dealu Bujorului vineyard exceeds the maximum allowed limit $(20 \mathrm{mg} / \mathrm{kg} \mathrm{Cu})$.
\end{abstract}

Keywords: multi-element composition; Romanian vineyard soil; wine.

Received: 09 August 2020 Accepted: 26 November 2020 Published: 4 May 2021

DOI:

10.15835/buasvmcn-hort:2020.0021

\section{INTRODUCTION}

Without doubt, the determination of macro-, micro-elements, and also heavy metals in different types of food samples is of high importance for several reasons, the most important one being the nutritional, as well as toxic effects of these elements or their compounds (Płotka-Wasylka et al., 2018). Knowledge of levels of macro-, micro-elements, and heavy metals in alcoholic beverages such as wine is also very important, because in many countries, they constitute more than $12 \%$ of the consumption of alcoholic beverages (Płotka-Wasylka et al, 2018), therefore, they could be an important source of several metal ions. Due to their toxic effect on the human body in case of excessive intake, the determination of certain elements in wines is routinely carried out in most oenological laboratories because some heavy metals must be kept under control according to the International Organisation of Vine and Wine law (O.I.V., 2016).

Wine is a drink whit great social and economic significance widely consumed around the world, it has a complex matrix which, besides water, sugar, acids, tannins and alcohol, contains a great variety of organic as well as inorganic components (Zinicovscaia et al., 2017).

Among the various components that contribute to its quality and nutritional value are macro-, microelements and whose concentrations may be quite variable 
(Galgano et al., 2008). As in many wine-producing European countries, a controlled denomination of origin was established in Romania to guarantee the provenance and quality of its wines, and also to prevent frauds.

A great number of natural and anthropogenic factors such as soil characteristics (Dalipi et al., 2015), type of grape (Zinicovscaia et al., 2017), area of production (Paneque et al., 2017), environmental conditions, fertilizers (Đurđić et al., 2017), inorganic pesticides (Fabani et al., 2010), wine-making practices (Ivanova-Peropulos et al., 2013), application of additives (Šperková and Suchanek, 2005), transport and storage (Grindaly et al., 2011) could significantly influence the levels of macro-, micro-elements, lanthanides and heavy metals (Bora et al., 2017). Wines from vineyards located near to road traffic, and in industrial areas contain a higher concentration of $\mathrm{Cd}$ and $\mathrm{Pb}$ because of vehicle exhaust fumes or other emissions to air, water and soil (Pohl, 2007).

Besides, the elemental composition of wine depends directly on the applied winemaking process during different steps of production (Ivanova-Peropulos et al., 2016). Thus, contaminations could occur during the fermentation process (addition of yeasts, maceration), storage and aging process (the content of proteins, fining agents) (Ivanova-Peropulos et al., 2016). Furthermore, a longer contact of wine with the equipment produced from different materials (e.g. stainless, brass, steel and aluminum) used for handling and storing of the wine is a source of Cd, Al, Cr, Zn and Fe (Castiñeira Gómez et al., 2004, Lara et al., 2005, Pohl, 2007, Cheng and Liang, 2012, Volpe et al., 2009, Tariba, 2011, Hopfer et al., 2013, Ivanova-Peropulos et al., 2016, Bora et al., 2017, Bekker et al., 2019).

During the technological process of winemaking, the concentration of elements is changing mainly due to the precipitation of $\mathrm{Ca}$ and $\mathrm{K}$ tartrates as well as precipitation of $\mathrm{Al}, \mathrm{Cr}, \mathrm{Cu}, \mathrm{Fe}, \mathrm{Mn}, \mathrm{Ni}, \mathrm{Pb}$, and $\mathrm{Zn}$ (Mozaz et al., 1999). Furthermore, the concentration of elements in wine could be modified by the presence of living or non-living Saccharomyces cerevisiae yeast lowering significantly the final levels of some metals (Ivanova-Peropulos et al., 2016). Yeast consumes $\mathrm{Mg}, \mathrm{Ca}, \mathrm{Cu}, \mathrm{Fe}$ and $\mathrm{Zn}$ causing a decrease in their content during fermentation (Nicolini and Larcher, 2003).

Daily consumption of wine in moderate quantities contributes significantly to the requirements of the human organism for essential elements, such as $\mathrm{Ca}, \mathrm{Cr}, \mathrm{Co}, \mathrm{K}, \mathrm{Se}$ and $\mathrm{Zn}$, however above optimal concentration, elements such as $\mathrm{Al}, \mathrm{Cu}, \mathrm{K}, \mathrm{Fe}, \mathrm{Mn}$ and $\mathrm{Zn}$, may have detrimental effects on the stability of wine and its commercial acceptability, while $\mathrm{Pb}, \mathrm{Cd}$ and $\mathrm{Pb}$ are known to be potential toxic (Galgano et al., 2008).

The wine typically contains major elements $\mathrm{Na}, \mathrm{Mg}, \mathrm{K}$ and $\mathrm{Ca}$, whose concentration is greater than $10 \mathrm{mg} / \mathrm{L}$; trace elements $\mathrm{Al}, \mathrm{Mn}, \mathrm{Fe}, \mathrm{Zn}$ and $\mathrm{Pb}$, whose concentration overpass $10 \mu \mathrm{g} / \mathrm{L}$; and ultra-trace elements $\mathrm{Cr}, \mathrm{Ni}$, As and $\mathrm{Cd}$, whose concentration is lower than $\mu \mathrm{g} / \mathrm{L}$ (Zinicovscaia et al., 2017). Even if the list of elements commonly found in wines is much larger, we have restained to those elements which are either major components of vineyard soil or are more or less related to human activity, for this reason, the determination of the metal's concentration, in the last ten years (Bora et al., 2020), moreover, the concentration of the same elements was successfully used to test the wine provenance or region of origin (Bora et al., 2018).

The determination of major and trace elements in wine from different vineyard regions of the world to survey the concentration of certain metals, and test de wine provenance or origin has been previously studied in countries like Slovakia, Czech Republic (Korenovska and Suhaj, 2005), France, Italy, Germany and Portugal (Giaccio and Vicentini, 2010), Spain (González et al., 2009), Hungary (Sass-Kiss et al., 2008), South Africa (Van Der Linde et al., 2010), Serbia (Đurđić et al., 2017), Moldavia (Zinicovscaia et al., 2017), Australia (Cozzolino et al., 2008), Greece (Galani-Nikolakaki et al., 2002), Romania (Bora et al., 2020).

Certain major and trace elements, such as $\mathrm{Na}, \mathrm{K}, \mathrm{Ca}, \mathrm{Fe}, \mathrm{Cu}$ and $\mathrm{Zn}$, show significant changes during the technological processes involved in winemaking and are a reason for the attention given to the elements in low or only in trace amounts (e.g., Cr, Co, Sb, Cs, Sc, Eu, Hf and Tl) (Geana et al., 2013), trace elements less affected by the winemaking processes are the alkaline earth metals, of which $\mathrm{Li}$ and $\mathrm{Rb}$ are the most relevant for geographical origin identification (Geana et al., 2013). According to the first research conducted fort the authentication of wines, the most frequently quantified and cited elements used for wine authentication are $\mathrm{K}, \mathrm{Na}, \mathrm{Fe}, \mathrm{Y}, \mathrm{Rb}, \mathrm{Ca}, \mathrm{Cu}, \mathrm{Cr}, \mathrm{Co}$, $\mathrm{Sb}, \mathrm{Cs}, \mathrm{Br}, \mathrm{Cs}, \mathrm{Br}, \mathrm{As}, \mathrm{Ag}, \mathrm{Li}, \mathrm{Ba}, \mathrm{Sr}, \mathrm{Mg}, \mathrm{Al}$ and Mn (Arvanitoyannis et al., 1999). For Romania, according to studies performed to date, the main elements allowing differentiation between wines are Mn, Sr (Suhaj and Korenovska, 2005), Cr, Sr, Ag, Co (Geana et al., 2013) and Hg, Al, Tl and U (Bora et al., 2018).

The ability to make a distinction between wines by vineyard regions through their trace elements patterns suggests that the elements are mainly regulated by the movement from the rock to vineyard soil, and from vineyard soil to grapevine; wine multi-elemental composition is strongly influenced by the solubility of inorganic compounds from vineyard soil from which we conclude that the pattern of wine will reflect the geochemistry of the provenance soil (Galgano et al., 2008). Nevertheless, several factors may change markedly the multielement composition of wine and may endanger the relationship between wine and vineyard soil components such as environmental contamination, agricultural practices, climatic changes, vinification processes (Suhaj and Korenovska, 2005). Therefore, the utilization of the multi-element pattern as a distinction between wines by vineyard regions has to be confined to high-quality wines produced from specific vine varieties and whose influence of the vinification processes on the wine patterns had been previously studied and permanently controlled (Almeida and Vasconcelos, 2003) a complete qualitative analysis was carried out in previous research (Bora et al., 2016).

Complete wine classification and the distinction between wines by vineyard regions should be accomplished by using different instrumental techniques (De Villiers et al., 2012), such as chromatographic methods like high 
performed liquid chromatography (HPLC) (Fraige et al., 2014), infrared spectroscopy (IR) (Bevin et al., 2008), gas chromatography (GC) (Weldegergis et al., 2011), mass spectrometry (MS) (De Villiers et al., 2012), nuclear magnetic resonance (NMR) (Godelmann et al., 2013) coupled with different detectors, having, as a result, a large quantity of data, from which the essential information must be analyzed using chemometric techniques (De Villiers et al., 2012).

Among the multielement techniques used so far, inductively coupled plasma mass spectrometry (ICP-MS) excels with true multielement capabilities together with extremely low detection limits (Galgano et al., 2008). Day (1994) and Stroh et al. (1994) have been among the first in using ICP-MS to demonstrate the discriminant power of elements hitherto ignored, such as lanthanides. Analytical approaches used for the determination of element concentration from wines include a variety of techniques most commonly used atomic absorption spectroscopy (AAS) (Šelih et al., 2014), (ICP-MS) (Bora et al., 2020), inductively coupled plasma atomic emission spectroscopy (ICP-AES) (Lara et al., 2005), or x-ray fluorescence spectroscopy (XRF) spectrometry (Dalipi et al., 2015). Nowadays, the AAS technique is often replaced by ICP-AES and ICP-MS techniques because of the possibility of multi-elemental analysis, higher selectivity and sensitivity, and lower detection limits (Zinicovscaia et al., 2017). The main disadvantages of the ICP-MS techniques are the increase in the quantity of the solution alongside the increase in the number of the determining elements, the use of acids or other solvents, and interferences of organic components (Zinicovscaia et al., 2017). A critical factor for choosing the appropriate analytical method for the elemental characterization of wines was the multi-element detection capability with ICP-MS, a suitable technique for accurate and fast determination of macro-, micro-elements and heavy metals in the same sample (Geana et al., 2013).

The present study is focused on the determination of the mineral composition of international red wines (Merlot, Cabernet Sauvignon), white wines (Sauvignon blanc, Aligoté, Muscat Ottonel, Italian Riesling), native red wine (Feteasca neagră, Burgund mare, Băbeasca neagră) and white wines (Feteasca regală, Feteasca alba, Băbeasca gri, Șarba), produced in the Dealu Bujorului vineyard from Eastern region of Romania between 2014 and 2018, by using ICP-MS, and comparison of mineral composition of the vineyard soil.

The ICP-MS ensures very good detection and offers the right conditions for a reliable and fast determining method. We applied ICP-MS to sequentially determine the five macroelements ( $\mathrm{Ca}, \mathrm{K}, \mathrm{Na}, \mathrm{Mg}$ and $\mathrm{P}$ ), six trace elements ( $\mathrm{Fe}, \mathrm{Cu}, \mathrm{Mn}, \mathrm{Zn}, \mathrm{Li}$ and $\mathrm{Cr}$ ) and six heavy metals ( $\mathrm{Cd}, \mathrm{Pb}, \mathrm{Co}, \mathrm{As}, \mathrm{Hg}$ and $\mathrm{U}$ ) in 117 red and white wines and 50 soil samples. Because trace and heavy metals from wine samples impact on the organoleptic parameters of the drink but also human health, information on their existence, distribution, concentration and knowledge of existing relationships between metals and other parameters is crucial, and may be useful for the food industry, health professionals and consumers.

\section{MATERIALS AND METHODS}

\section{Study area}

The Dealu Bujorului vineyard is characterized by an alternate landscape, from flat to hilly areas, with an altitude between 100 and $225 \mathrm{~m}$, the predominant soil is levigated chernozem having a clayey sand texture with pH between 7.4 and 8.1 values (Bora et al., 2018). A total of 117 wine samples (45 red wines and 72 white wines) and 50 soil samples from the Dealu Bujorului vineyard were analyzed to determine the mineral composition.

The ecoclimatic conditions during the years of experience were investigated in previous works (Bora et al., 2019) concluding that: the duration of the growing season was in normal limits over 170 days, the thermal balance values obtained were higher than multiannual average [global thermal balance $\left(\sum \operatorname{tg}\right)$ was $3560.9^{\circ} \mathrm{C}\left(3484.0^{\circ} \mathrm{C}\right.$ multiannual average), active thermal balance $\left(\sum \mathrm{t}_{\mathrm{a}}\right)$ was $3526.6^{\circ} \mathrm{C}\left(3387.5^{\circ} \mathrm{C}\right.$ multiannual average $)$ and beneficial thermal balance $\left(\sum \mathrm{t}_{\mathrm{u}}\right)$ was $1736.6^{\circ} \mathrm{C}\left(1700.1^{\circ} \mathrm{C}\right)$ multiannual average] (Bora et al., 2019). The insolation coefficient $\left(\mathrm{C}_{\mathrm{i}}\right)$ recorded values of 8.8 this show an increase compared to the multiannual average (7.69) and the precipitation quantity was lower $(405.4 \mathrm{~mm}$ ) than the average of the last ten years $(505.7 \mathrm{~mm}$ ) (Bora et al., 2019).

\section{Sample collection and micro-vinification process}

The wines samples used in this experiment were obtained from the wines produced from international red wines (Merlot, Cabernet Sauvignon) white wines (Sauvignon blanc, Aligoté, Muscat Ottonel, Italian Riesling), native red wine (Feteasca neagră, Burgund mare, Băbeasca neagră) and white wines (Feteasca regală, Feteasca alba, Băbeasca gri, Șarba) produced in the Dealu Bujorului vineyard from East region of Romania between 2014 and 2018. The wines samples were obtained in the technological testing laboratory within Research Station for Viticulture and Enology Bujoru (RSVE Bujoru) from micro-wine production according to the methodology described by Bora et al. (2016) and taking into account the recommendations from (EC) Regulation No. 2729/2000, consolidated with EC Regulation No. 2030/2006. All wines were provided by the technological testing laboratory as finished wines in $750 \mathrm{~mL}$ glass bottles with cork stoppers and were stored at $3-4^{\circ} \mathrm{C}$ before analysis. All vines were planted since 1979, at RSVE Bujoru, and the vine plantation was organized with $2.2 \times 1 \mathrm{~m}$ distance between rows and plants. Vines were pruned according to the Guyot system and were grown on trellis. Soil sampling was carried out on the depth of the soil profile at 0-10 cm, 10-20 cm, 20-30 cm, 30-40 cm, 40-50 cm and 50-60 cm during 
2018 according to the methodology described by Bora et al. (2016). Soil samples were collected using stainless steel shovels and were store in individual black plastic bags, and all the samples were taken in triplicates from the defined experimental plot. Soil samples have been brought first to sand size material $(<2 \mathrm{~mm})$ using a jaw crusher than mechanically spit to obtained a representative sample, and eventually pulverized to powder-size, grain-size smaller than $100 \mu \mathrm{m}$, using a ball mill (Bora et al., 2019). Soil samples before splitting ant pulverization have been dried at $60^{\circ} \mathrm{C}$ (Bora et al., 2019).

\section{Sample preparation for determination of elements from wines and soils samples}

For the determination of elements from wines and soil samples, an amount of $0.5 \mathrm{~mL}$ wine and respectively 0.25 g soil were used and adjusted to $8 \mathrm{~mL}\left(7 \mathrm{~mL} \mathrm{HNO}_{3} 65 \%+1 \mathrm{~mL} \mathrm{H}_{2} \mathrm{O}_{2}\right.$ ), after 15-30 minutes the mineralization was performed using a microwave system Milestone START D Microwave Digestion System set in three steps: step I (time $10 \mathrm{~min}$., temperature $200^{\circ} \mathrm{C}$ ), step II (time $15 \mathrm{~min}$., temperature $200^{\circ} \mathrm{C}$ ), and step III (time $60 \mathrm{~min}$., ventilation $-35^{\circ} \mathrm{C}$ ). After mineralization, samples were filtered through a $0.45 \mathrm{~mm}$ filter and brought to a volume of $50 \mathrm{~mL}$ with $\mathrm{HNO}_{3}$ 1\% (Bora et al., 2019).

\section{Reagents and solutions}

Seventeen elements [five macroelements ( $\mathrm{Ca}, \mathrm{K}, \mathrm{Na}, \mathrm{Mg}$, and $\mathrm{P}$ ), six trace elements ( $\mathrm{Fe}, \mathrm{Cu}, \mathrm{Mn}, \mathrm{Zn}, \mathrm{Li}$, and $\mathrm{Cr}$ ) and six heavy metals ( $\mathrm{Cd}, \mathrm{Pb}, \mathrm{Co}, \mathrm{As}, \mathrm{Hg}$, and $\mathrm{U})]$ were determined to assess their concentration levels in wines produced in the Dealu Bujorului vineyard between 2014 and 2018 and comparison of mineral composition of the vineyard soil. The analysis was made as a multielement analysis with the ICP-MS technique, after appropriate dilution, using the external standard calibration method. The calibration was performed using XXICertiPUR multielement standard, and individual standard solution for $\mathrm{Hg}$ and $\mathrm{Cr}$. All reagents used were of the analytical grade or better, dilution and preparation of standards and samples we used $<18 \mathrm{M} \Omega / \mathrm{cm}$ ultrapure water supplied form Milli-Q Millipore system (Benford, MA, USA) and Tracepure ${ }^{\mathrm{TM}} \mathrm{HNO}_{3}$ from Merck (Darmstadt, Germany). The intermediate solution was stored in polyethylene bottles and glassware was cleaned by soaking in $10 \% \mathrm{v} / \mathrm{v} \mathrm{HNO}_{3}$ for 24 hours, and rinsing at least ten times with ultrapure water (Bora et al., 2019). The accuracy of the methods was evaluated by replicate analyses of known concentration samples, and the obtained values ranged between 0.3 to $14.8 \%$, depending on the element, and the global recovery for each element was between 84.6-100.2 (Bora et al., 2018). For quality control purposes, blanks and triplicates samples $(n=3)$ we analyzed during the procedure, the variation coefficient was under $5 \%$, detection limits ( $\mathrm{ppb}$ ) were determined by the calibration curve method. Limit of detection (LoD) and Limit of quantification (LoQ) were established in previous works (Bora et al., 2019), and was calculated according to the next mathematical formulas: $\mathrm{LoD}=3 \mathrm{SD} / \mathrm{s}$ and $\mathrm{LoQ}=10 \mathrm{SD} / \mathrm{s}$ (SD = estimation of the standard deviation of the regression line; $\mathrm{s}=$ slope of the calibration curve) (Table 1).

Table 1. Calibration conditions for the determination of each element

\begin{tabular}{cccccccccc}
\hline Element & $\begin{array}{c}\text { Correlation } \\
\text { coefficient }\end{array}$ & $\begin{array}{c}\text { LoD* } \\
(\mu \mathrm{g} / \mathrm{L})\end{array}$ & $\begin{array}{c}\text { LoQ*** } \\
(\mu \mathrm{g} / \mathrm{L})\end{array}$ & $\begin{array}{c}\mathrm{BEC}^{* *} \\
(\mu \mathrm{g} / \mathrm{L})\end{array}$ & Element & $\begin{array}{c}\text { Correlation } \\
\text { coefficient }\end{array}$ & $\begin{array}{c}\text { LoD* } \\
(\mu \mathrm{g} / \mathrm{L})\end{array}$ & $\begin{array}{c}\text { LoQ*** } \\
(\mu \mathrm{g} / \mathrm{L})\end{array}$ & $\begin{array}{c}\text { BEC** } \\
(\mu \mathrm{g} / \mathrm{L})\end{array}$ \\
\hline $\mathrm{As}$ & 0.9999 & 0.2335 & 0.7776 & 0.538 & $\mathrm{~K}$ & 0.9999 & 2.1860 & 7.2794 & 31.728 \\
\hline $\mathrm{Ca}$ & 0.9999 & 5.6649 & 18.8641 & 20.820 & $\mathrm{Li}$ & 0.9999 & 0.0048 & 0.0160 & 0.020 \\
\hline $\mathrm{Cd}$ & 0.9999 & 0.0202 & 0.0673 & 0.027 & $\mathrm{Mg}$ & 0.9999 & 2.7325 & 9.0992 & 9.099 \\
\hline $\mathrm{Co}$ & 0.9999 & 0.0365 & 0.1215 & 0.152 & $\mathrm{Mn}$ & 0.9999 & 0.0102 & 0.0340 & 0.085 \\
\hline $\mathrm{Cr}$ & 0.9999 & 1.6630 & 5.5378 & 0.636 & $\mathrm{Na}$ & 0.9999 & 3.9808 & 13.2561 & 32.121 \\
\hline $\mathrm{Cu}$ & 0.9999 & 0.0402 & 0.1339 & 0.237 & $\mathrm{P}$ & 0.9999 & 3.4712 & 15.054 & 35.745 \\
\hline $\mathrm{Pb}$ & 0.9999 & 0.0003 & 0.0010 & 0.002 & $\mathrm{Ni}$ & 0.9999 & 0.0591 & 0.1968 & 0.091 \\
\hline $\mathrm{Zn}$ & 0.9999 & 0.3780 & 1.2587 & 5.401 & $\mathrm{U}$ & 0.9999 & 0.0253 & 0.0842 & 0.005 \\
\hline $\mathrm{Hg}$ & 0.9999 & 0.0417 & 0.1379 & 0.128 & & & & & \\
\hline
\end{tabular}

* Detection limit; **Background equivalent concentration; ${ }^{* * *}$ Quantification limit

A quantitative measure of background level, the 'Background Equivalent Concentration' (BEC), which is defined as the concentration of a given element that exhibits the same intensity as the background, measured at a given wavelength (ICP-OES) or mass (ICP-MS).

$\mathrm{BEC}$ is calculated with the following formula:

$$
\mathrm{BEC}=\frac{\mathrm{I} \text { blank }}{\mathrm{I} \text { standard }-\mathrm{I} \text { blank }} \times \mathrm{C} \text { standard }
$$

I blanc $=$ intensity of the blank

I standard = intensity of the standard

I standard $=$ concentration of the standard 


\section{Instrumentation}

The determination of metals was performed on a mass spectrometer with inductively coupled plasma, (ICP-MS) iCAP Q Thermo scientific model, based polyatomic species before they reach the quadrupole mass spectrometer, using a perfluoroalkoxy alkanes (PFA) microflow concentric nebulizer. The argon used was of $99.99 \%$ purity (Messer, Austria). The instrument was daily optimized to give maximum sensitivity for $\mathrm{M}^{+}$ions and the double ionization and oxides monitored by the means of the ratios between $\mathrm{Ba}^{2+} / \mathrm{Ba}^{+}$and $\mathrm{Ce}^{2+} / \mathrm{CeO}^{+}$, respectively, these always being less than $2 \%$. The experimental conditions were: argon flow on a nebulizer $(0.80 \mathrm{~L} / \mathrm{min}$.), auxiliary gas flow $0.80 \mathrm{~L} / \mathrm{min}$., argon flow in plasma $15 \mathrm{~L} / \mathrm{min}$., lens voltage $7.31 \mathrm{~V}$; (RF) power in plasma $1100 \mathrm{~W}$, spray chamber temperature $\left(2.51 \pm 1.00{ }^{\circ} \mathrm{C}\right)$. Accuracy was calculated for the elements taken into consideration $(0.5-5.0 \%)$ and was established in previous works (Bora et al., 2017, Bora et al., 2019).

\section{Statistical analysis}

The statistical interpretation of the results was performed using the Duncan test, Statistical Package of the Social Sciences - SPSS Version 24 (SPSS Inc., Chicago, IL., USA). The statistical processing of the results was primarily performed to calculate the following statistical parameters: arithmetic average, standard deviation, standard error. This data was interpreted with the analysis of variance (ANOVA) and the average separation was performed with the DUNCAN test at $p \leq 0.05$.

\section{RESULTS AND DISCUSSIONS}

High dispersion of elements concentration observed in wines was also described in the literature (Bimpilas et al., 2015; Nelson et al., 2015; Bekker et al., 2019). Our results showed that the elemental concentrations of wine and soil were interrelated. Tables 2, 3 and 4 presented the concentration of the elements from wine and Tables 5, 6 and 7 in soils. The average concentrations of elements in the soil decrease in the following order: $\mathrm{K}(703.46 \pm 154.31$ $\mathrm{mg} / \mathrm{kg}), \mathrm{Na}(162.39 \pm 24.20 \mathrm{mg} / \mathrm{kg})$ and $\mathrm{Ca}(123.04 \pm 24.05 \mathrm{mg} / \mathrm{kg}$ ) (Table 5), Cu (91.59 $\pm 28.62 \mathrm{mg} / \mathrm{kg}) \mathrm{and} \mathrm{Fe}$ $(80.91 \pm 20.65 \mathrm{mg} / \mathrm{kg})$ (Table 6), P (68.68 $\pm 14.60 \mathrm{mg} / \mathrm{kg})$ and $\mathrm{Mg}(58.36 \pm 13.44 \mathrm{mg} / \mathrm{kg})(\mathrm{Table} 5), \mathrm{Li}(41.84 \pm$ $35.72 \mathrm{mg} / \mathrm{kg}$ ) (Table 6), Co (14.37 $\pm 5.20 \mathrm{mg} / \mathrm{kg}$ ) (Table 7), Mn (10.84 $\pm 3.84 \mathrm{mg} / \mathrm{kg})$ and $\mathrm{Zn}(6.15 \pm 1.14 \mathrm{mg} / \mathrm{kg})$ (Table 6), $\mathrm{Pb}(5.65 \pm 2.42 \mathrm{mg} / \mathrm{kg}$ ) (Table 7), $\mathrm{Cr}(5.35 \pm 2.47 \mathrm{mg} / \mathrm{kg}$ ) (Table 6), As (0.96 $\pm 0.29 \mathrm{mg} / \mathrm{kg}), \mathrm{U}(0.48 \pm 0.13$ $\mathrm{mg} / \mathrm{kg}), \mathrm{Cd}(0.28 \pm 0.10 \mathrm{mg} / \mathrm{kg})$ and $\mathrm{Hg}(0.070 \pm 0.015 \mathrm{mg} / \mathrm{kg})$ (Table 7). The soil contained essential major elements for grapevine growth. The constituents of major elements in soils are affected by the composition of the soil. A similar trend was observed in some previous studies (Núñez et al., 2000; Thiel et al., 2004; Banović et al., 2009; Karataș et al., 2015).

According to the results shown in Tables 2, 3 and 4, the highest concentration of $\mathrm{Ca}, \mathrm{K}, \mathrm{Na}, \mathrm{Mg}$ and $\mathrm{P}$ were found in Sauvignon blanc (101.92 $\pm 3.73 \mathrm{mg} / \mathrm{L} \mathrm{Ca}$ ), Cabernet Sauvignon (496.41 $\pm 6.20 \mathrm{mg} / \mathrm{L} \mathrm{K} ; 241.84 \pm 11.95 \mathrm{mg} / \mathrm{L} \mathrm{P}$ ), Feteasca neagră (47.00 $\pm 6.35 \mathrm{mg} / \mathrm{L} \mathrm{Na})$, Muscat Ottonel $(227.71 \pm 4.16 \mathrm{mg} / \mathrm{kg} \mathrm{Mg})$. The concentration of Ca and Mg in wine was influenced by years, while $\mathrm{K}, \mathrm{Na}$ and $\mathrm{P}$ were not influenced by this factor. The concentration of these macro-elements found in wine was influenced by the variety of vines and also by the interaction betwe en the year of culture and vine variety. Research conducted by Karatas et al. (2015) concludes that the year of culture did not have any effects on the macro-element levels of Cabernet Sauvignon, Cot and Boğazhere but macroelement values changed by years in Syrah, Merlot and Tanat wines (Karatas et al., 2015). The average concentrations of the major elements (content $>1 \mathrm{mg} / \mathrm{L}$ ) in the studied wines decreased in the order $\mathrm{K}>\mathrm{Mg}>\mathrm{P}>\mathrm{Ca}>\mathrm{Na}$. The results agree with values reported in the literature (average values reported by Iglesias et al. (2007) $819 \mathrm{mg} / \mathrm{L} \mathrm{K}$ and 865.30 $\mathrm{mg} / \mathrm{L} \mathrm{K}$ reported by Álvarez et al. (2012). The values obtained for the $\mathrm{Ca}, \mathrm{Mg}$, and $\mathrm{P}$ contents in our selected wines were in good agreement with the results for Macedonian wine (Ivanova-Peropulos et al., 2016) average value of $83.5 \mathrm{mg} \mathrm{Ca} / \mathrm{L} ; 98.20 \mathrm{mg} / \mathrm{L} \mathrm{Mg}$ and $114 \mathrm{mg} / \mathrm{L} \mathrm{P}$ ), Serbian wine (Ražić, and Onijia, 2010) average value of $37 \mathrm{mg} / \mathrm{Ca}$ $\mathrm{L}$ and $95.73 \mathrm{mg} / \mathrm{L} \mathrm{Mg}$, Croatian wine (Vrček et al., 2011) average value of $65.90 \mathrm{mg} / \mathrm{L} \mathrm{Ca}$ and $68.70 \mathrm{mg} / \mathrm{L} \mathrm{Mg}$ and also in Czech wines (Kment et al., 2005) average value of $108.00 \mathrm{mg} / \mathrm{L} \mathrm{Ca}$ and $75.40 \mathrm{mg} / \mathrm{L} \mathrm{Mg.} \mathrm{On} \mathrm{the} \mathrm{other} \mathrm{hand,}$ $\mathrm{Ca}$ and $\mathrm{Mg}$ contents were significantly higher than the values described in the literature by other authors as Lara et al. (2005) (average value of $12.50 \mathrm{mg} / \mathrm{L} \mathrm{Ca} \mathrm{-} \mathrm{Argentine} \mathrm{wines)} \mathrm{and} \mathrm{Coetzee} \mathrm{et} \mathrm{al.} \mathrm{(2014)} \mathrm{(average} \mathrm{value} \mathrm{of} 12.05$ $\mathrm{mg} / \mathrm{L} \mathrm{Mg}$ and $6.73 \mathrm{mg} / \mathrm{L} \mathrm{Ca}-$ Belgium wines).

$\mathrm{Ca}$ and $\mathrm{K}$ are the natural components of the grape, also $\mathrm{K}$ is the element with the highest concentration in the juice produced by Vitis vinifera (Fabani et al., 2010), but its highest concentration is affected by the precipitation of wine during stabilization and aging by the formation of potassium bitartrate and calcium tartrate crystals (Lara et al., 2005). Additional amounts of $\mathrm{K}$ to wine composition can be introduced using potassium bisulfite or potassium metabisulfite during the winemaking process, but this is not our case due to the fact the practice for the wine clarification is to use sulfur dioxide (Bora et al., 2016).

The sodium concentration in wines was determined primarily by the composition of a soil where vines were grown (with soil salinity depending on the proximity of the sea) and water used for their watering (Pohl, 2007, Watson et al., 2004, Stępień et al., 2015). High Na concentration was observed in wines originating from Spain, Australian, and Macedonia (Pohl, 2007). There is a limit for Na concentration in wines, introduced in some countries due to health risk concerns. Specifically, O.I.V. (2016) recommends that the maximal concentration may not exceed $60 \mathrm{mg} / \mathrm{L}$. As you can 
see the values obtained were well below the maximum allowed values, the highest value was recorded by the Feteasca neagră $(47.00 \pm 6.35 \mathrm{mg} / \mathrm{L})$.

The presence of Mg in wines is dependent on the natural content in grape (Álvarez et al., 2007), it is a micronutrient in plants being an essential element in the chlorophyll molecule and, together with Ca contributes to the structure of the cell walls (Bora et al., 2017). Mg concentration in wines is quite stable in the analysed wines. In most samples, the concentration varied in the range of $91.81 \pm 3.45 \mathrm{mg} / \mathrm{L} \mathrm{Mg}$ to $227.71 \pm 4.16 \mathrm{mg} / \mathrm{L} \mathrm{Mg}$ with an average of $125.60 \pm 5.71 \mathrm{mg} / \mathrm{L} \mathrm{Mg}$.

Phosphorus participates in the nutrition of vines, with the formation of nucleoproteins in cells that make up the grape pulp, the most important nucleic acids are (DNA) and (ARN) which contain 10\% P. Phosphorus from the composition of nucleic acids is the one that stores and transforms energy into biochemical processes in the plant (Târdea, 2007). It is also part of the composition of Adenosine Triphosphate (ATP) and Adenosine Diphosphate (ADP) coenzymes that participate in the phosphorylation of sugars in the process of alcoholic fermentation, with an important role in the energy balance of this process. Of the total phosphorus present in wine, organic phosphorus represents $10-30 \%$, and by the addition of ammonium phosphate in fermentation must, for yeast feed, the wine is enriched with the mineral phosphorus (Târdea, 2007). The measured values ranged between $221.59 \pm 4.49 \mathrm{mg} / \mathrm{L}$ $\mathrm{P}$ for red wines and $317.76 \pm 3.16 \mathrm{mg} / \mathrm{L} \mathrm{P}$ for white wines, the highest values were recorded in the Cabernet Sauvignon variety and Băbească neagră. These results agree with values reported in the literature (IvanovaPeropulos et al., 2016 - average values of $115 \mathrm{mg} / \mathrm{L}$ P for red wines). The mean content of the majority of these elements in the Romanian wines is similar with the values described in the literature by other authors (Kment et al., 2005, Fabani et al., 2010, Dehelean et al., 2012, Geana et al., 2013, Geana et al., 2014, Bora et al., 2016, Geana et al., 2016, Bora et al., 2019).

The iron content in wines is conditioned by several factors, like the vineyard soil and the fertilizers used during winemaking (Kment et al., 2005, Lara et al., 2005, Geana et al., 2014), the evaluation of Fe content in wines is of major importance due to changes in wine stability that it may cause as well as its effects on oxidation and wine aging (Frías et al., 2011). At concentration $>10 \mathrm{mg} / \mathrm{L}$, Fe (III) creates insoluble suspensions with tannin and phosphates which are known as hazes or cases (Paleologos et al., 2002). Fe is of importance to the winemaker because when it is present at $>7-10 \mathrm{mg} / \mathrm{L}$, it may cause cloudiness or colour change; the content depends upon Fe levels in soil and dust, and contamination during harvesting, transportation, and processing (Lazos et al., 1989). All wines had Fe contents over the $7 \mathrm{mg} / \mathrm{L}$ limit (mean value was $13.26 \pm 1.42 \mathrm{mg} / \mathrm{L} \mathrm{Fe}$ ) considered being the minimum concentration necessary to form ferric cases. The highest Fe level was observed in the Dealu Bujorului cultivar, and this amount of $\mathrm{Fe}$ in the soil (Table 6) is associated with the characteristics of the soil as well as the equipment and the stabilization treatments (Karataș et al., 2015). The results agree with values reported in the literature in the wines produced in Turkey (Cabernet Sauvignon $14.23 \pm 3.15 \mathrm{mg} / \mathrm{L} \mathrm{Fe}$, and Merlot $13.98 \pm 1.59 \mathrm{mg} / \mathrm{L} \mathrm{Fe}$ ) (Karataș et al., 2015).

The presence of $\mathrm{Cu}$ in wines comes naturally from vineyard soil, is usually associated with the addition of pesticides and the winemaking process (Kment et al., 2005). All wines samples have Cu concentration below $1 \mathrm{mg} / \mathrm{L}$ recommended by O.I.V. (2016) to prevent the formation of cupric cases, so there is no risk of them. Cu concentration was within wide limits, Feteasca regala variety $0.87 \pm 0.11 \mathrm{mg} / \mathrm{L} \mathrm{Cu})$ recorded the highest concentration and at the opposite pole was Băbeasca gri variety $(0.17 \pm 0.02 \mathrm{mg} / \mathrm{L} \mathrm{Cu})$ which recorded the lowest concentration, the average value of $\mathrm{Cu}$ concentration in wine was $0.52 \pm 0.12 \mathrm{mg} / \mathrm{L} \mathrm{Cu}$, a value that is significantly lower than the maximum permissible limit. 
Table 2. Determination of macroelements in wines from Dealu Bujorului vineyard by ICP-MS (mg/L); (mean \pm SD)

\begin{tabular}{|c|c|c|c|c|c|c|c|}
\hline Area & Variety & Vintage & $\mathrm{Ca}$ & $\mathrm{K}$ & $\mathrm{Na}(\mathrm{MPL}=60 \mathrm{mg} / \mathrm{L})$ & $\mathrm{Mg}$ & $\mathrm{P}$ \\
\hline \multirow{38}{*}{ 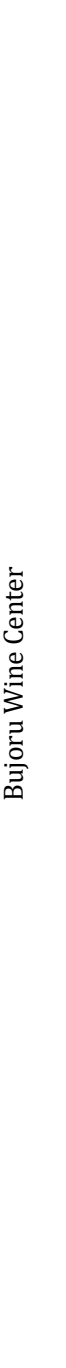 } & \multirow{4}{*}{ Merlot } & 2014 & $62.29 \pm 3.23 \mathrm{ghi}$ & $351.04 \pm 4.68^{\mathrm{d}}$ & $22.97 \pm 1.52$ hijk & $121.81 \pm 13.76^{\mathrm{ij} j \mathrm{klmn}}$ & $120.02 \pm 6.38$ defg \\
\hline & & 2016 & $68.74 \pm 7.77$ efg & $343.34 \pm 11.12 \mathrm{de}$ & $21.48 \pm 1.74^{\mathrm{ijk}}$ & $150.19 \pm 3.76$ ef & $121.57 \pm 15.62$ defg \\
\hline & & 2018 & $66.28 \pm 5.89$ fgh & $359.59 \pm 6.83^{d}$ & $23.37 \pm 1.21^{\mathrm{hijk}}$ & $150.78 \pm 2.69$ ef & $109.70 \pm 15.30$ ghi \\
\hline & & Average & $65.77 \pm 2.28$ & $351.53 \pm 3.28$ & $22.61 \pm 0.27$ & $142.92 \pm 6.10$ & $117.10 \pm 5.24$ \\
\hline & \multirow{4}{*}{$\begin{array}{l}\text { Cabernet } \\
\text { Sauvignon }\end{array}$} & 2014 & $61.04 \pm 6.28$ ghijk & $496.41 \pm 6.20^{a}$ & $36.63 \pm 5.80 \mathrm{bc}$ & $120.67 \pm 6.34$ ijklmn & $241.84 \pm 11.95$ a \\
\hline & & 2015 & $49.60 \pm 8.93^{1}$ & $467.51 \pm 10.08^{b}$ & $42.27 \pm 1.00 \mathrm{ab}$ & $127.45 \pm 5.64 \mathrm{hij}$ & $191.40 \pm 6.97 \mathrm{bc}$ \\
\hline & & 2016 & $51.11 \pm 3.40 \mathrm{kl}$ & $440.58 \pm 14.84 \mathrm{c}$ & $36.01 \pm 2.11 \mathrm{bcd}$ & $124.78 \pm 6.57 \mathrm{ijkl}$ & $182.94 \pm 15.01^{\mathrm{c}}$ \\
\hline & & Average & $53.92 \pm 2.77$ & $468.17 \pm 4.33$ & $38.30 \pm 2.51$ & $124.30 \pm 0.49$ & $196.39 \pm 4.05$ \\
\hline & \multirow{3}{*}{ Feteasca neagră } & 2014 & $56.37 \pm 10.90$ hijkl & $355.75 \pm 10.05 \mathrm{~d}$ & $47.00 \pm 6.35^{a}$ & $122.96 \pm 11.82^{\mathrm{ijklm}}$ & $131.53 \pm 11.39 \mathrm{de}$ \\
\hline & & 2015 & $46.70 \pm 2.28^{1}$ & $332.93 \pm 9.03$ ef & $36.15 \pm 2.07 \mathrm{bc}$ & $120.74 \pm 9.39 \mathrm{ijklmn}$ & $114.85 \pm 7.48$ efgh \\
\hline & & Average & $52.66 \pm 4.92$ & $326.78 \pm 2.18$ & $39.69 \pm 2.19$ & $119.28 \pm 2.84$ & $125.70 \pm 4.85$ \\
\hline & \multirow{4}{*}{ Burgund Mare } & 2016 & $24.77 \pm 1.36^{\mathrm{n}}$ & $226.74 \pm 10.78^{\mathrm{jk}}$ & $17.44 \pm 6.19 \mathrm{klm}$ & $106.74 \pm 6.69$ mnop & $100.50 \pm 2.70^{\text {fghi }}$ \\
\hline & & 2017 & $27.28 \pm 0.72 \mathrm{mn}$ & $249.00 \pm 6.44 \mathrm{hi}$ & $24.11 \pm 6.19$ ghijk & $110.74 \pm 11.23$ Imnop & $110.78 \pm 11.17$ fghi \\
\hline & & 2018 & $19.34 \pm 2.66^{\mathrm{n}}$ & $211.85 \pm 2.35 \mathrm{kl}$ & $22.96 \pm 1.59$ hijk & $111.04 \pm 1.23 \mathrm{Imnop}$ & $105.69 \pm 3.37$ ghij \\
\hline & & Average & $24.81 \pm 0.99$ & $229.20 \pm 4.21$ & $21.51 \pm 2.34$ & $109.51 \pm 5.02$ & $105.69 \pm 3.37$ \\
\hline & \multirow{4}{*}{ Băbeasca neagră } & 2015 & $26.77 \pm 6.73 \mathrm{mn}$ & $147.96 \pm 11.91 \mathrm{~m}$ & $9.96 \pm 2.11^{n}$ & $92.37 \pm 14.98^{\mathrm{r}}$ & $186.87 \pm 10.85 \mathrm{bc}$ \\
\hline & & 2016 & $32.45 \pm 1.29 \mathrm{~m}$ & $237.12 \pm 8.44 \mathrm{ij}$ & $13.29 \pm 0.96 \mathrm{lmn}$ & $99.93 \pm 2.09$ opr & $190.90 \pm 10.85 \mathrm{bc}$ \\
\hline & & 2017 & $32.45 \pm 1.06 \mathrm{mn}$ & $254.26 \pm 11.06^{h}$ & $17.34 \pm 7.50 \mathrm{klm}$ & $88.81 \pm 1.06^{r}$ & $202.89 \pm 6.51 \mathrm{ab}$ \\
\hline & & Average & $30.47 \pm 3.21$ & $213.11 \pm 1.81$ & $13.53 \pm 3.50$ & $93.70 \pm 7.76$ & $193.55 \pm 2.20$ \\
\hline & \multirow{3}{*}{ Feteasca regală } & 2015 & $60.18 \pm 6.69$ ghij & $123.67 \pm 11.12^{n}$ & $32.56 \pm 1.53^{\text {cdef }}$ & $141.78 \pm 1.79^{f g}$ & $67.99 \pm 8.29$ ор \\
\hline & & 2017 & $69.84 \pm 9.64$ efg & $119.89 \pm 6.77^{n}$ & $30.22 \pm 1.62$ cdefg & $109.73 \pm 2.58$ Imnop & $50.36 \pm 7.58^{\mathrm{r}}$ \\
\hline & & Average & $68.04 \pm 3.52$ & $123.04 \pm 3.64$ & $31.70 \pm 0.27$ & $125.19 \pm 0.69$ & $66.86 \pm 0.52$ \\
\hline & \multirow{4}{*}{ Feteasca albă } & 2015 & $89.55 \pm 6.42 \mathrm{~b}$ & $226.30 \pm 17.28^{j \mathrm{k}}$ & $22.97 \pm 1.59$ hijk & $71.04 \pm 4.77 \mathrm{q}$ & $76.07 \pm 7.72$ mnop \\
\hline & & 2016 & $93.23 \pm 3.04 \mathrm{~b}$ & $236.23 \pm 7.81^{\mathrm{ij}}$ & $25.23 \pm 5.70^{\text {fghij }}$ & $69.19 \pm 3.57 \mathrm{q}$ & $58.60 \pm 15.09 \mathrm{pr}$ \\
\hline & & 2018 & $76.56 \pm 0.95$ cde & $197.60 \pm 7.12^{1}$ & $29.11 \pm 1.96^{\text {defgh }}$ & $65.78 \pm 4.15 q$ & $79.16 \pm 7.06^{1 \mathrm{mno}}$ \\
\hline & & Average & $83.30 \pm 2.76$ & $220.04 \pm 5.68$ & $25.77 \pm 2.27$ & $68.67 \pm 0.60$ & $71.28 \pm 4.46$ \\
\hline & \multirow{4}{*}{ Băbeasca gri } & 2014 & $86.99 \pm 7.15^{b}$ & $205.33 \pm 7.03^{1}$ & $6.96 \pm 2.74^{\mathrm{n}}$ & $182.56 \pm 8.22^{c}$ & $133.25 \pm 12.65^{\mathrm{d}}$ \\
\hline & & 2015 & $90.40 \pm 2.45 \mathrm{~b}$ & $202.41 \pm 11.43^{1}$ & $10.30 \pm 2.28^{\mathrm{n}}$ & $182.67 \pm 4.92^{c}$ & $127.60 \pm 5.53 \mathrm{def}$ \\
\hline & & 2016 & $87.86 \pm 3.11^{b}$ & $321.93 \pm 9.96^{f}$ & $11.14 \pm 1.23^{n}$ & $166.59 \pm 9.89 \mathrm{~d}$ & $100.25 \pm 1.93$ hijk \\
\hline & & Average & $89.55 \pm 3.11$ & $243.22 \pm 2.24$ & $9.47 \pm 0.77$ & $177.27 \pm 2.53$ & $120.37 \pm 5.45$ \\
\hline & \multirow{4}{*}{ Șarba } & 2014 & $47.55 \pm 3.18^{1}$ & $351.97 \pm 5.84 \mathrm{~d}$ & $18.89 \pm 2.08^{\mathrm{jkl}}$ & $132.26 \pm 2.66$ ghi & $70.01 \pm 3.93$ nop \\
\hline & & 2015 & $61.54 \pm 4.02$ ghij & $255.63 \pm 11.00^{\mathrm{h}}$ & $19.66 \pm 1.35^{\mathrm{ijkl}}$ & $150.56 \pm 5.51$ ef & $75.36 \pm 6.00 \mathrm{mnop}$ \\
\hline & & 2016 & $54.56 \pm 4.99^{\mathrm{ijkl}}$ & $230.78 \pm 0.77 \mathrm{j}$ & $20.82 \pm 0.80^{\mathrm{ijk}}$ & $118.90 \pm 5.83 \mathrm{jklmno}$ & $75.69 \pm 7.69$ mор \\
\hline & & Average & $53.66 \pm 0.90$ & $279.46 \pm 5.11$ & $19.79 \pm 0.64$ & $133.91 \pm 1.74$ & $73.69 \pm 1.88$ \\
\hline & \multirow{4}{*}{ Aligoté } & 2014 & $88.74 \pm 4.99^{b}$ & $203.74 \pm 12.18^{1}$ & $34.78 \pm 3.86^{\mathrm{cd}}$ & $113.08 \pm 5.33 \mathrm{lmnop}$ & $104.81 \pm 8.49$ ghij \\
\hline & & 2015 & $89.45 \pm 3.89 \mathrm{~b}$ & $347.93 \pm 7.33 \mathrm{de}$ & $30.78 \pm 1.71$ cdefg & $104.81 \pm 5.26$ nор & $109.18 \pm 3.42 \mathrm{ghi}$ \\
\hline & & 2016 & $86.33 \pm 3.12^{b}$ & $355.97 \pm 1050 \mathrm{~d}$ & $26.66 \pm 2.85$ efghi & $123.31 \pm 11.00$ i jklm & $106.48 \pm 2.85$ ghij \\
\hline & & Average & $88.17 \pm 0.48$ & $302.55 \pm 2.46$ & $30.74 \pm 1.08$ & $113.73 \pm 3.30$ & $106.82 \pm 3.10$ \\
\hline
\end{tabular}

23| VOLUME 78 ISSUE 1 | MAY 


\begin{tabular}{|c|c|c|c|c|c|c|c|}
\hline Area & Variety & Vintage & $\mathrm{Ca}$ & $\mathrm{K}$ & $\mathrm{Na}(\mathrm{MPL}=60 \mathrm{mg} / \mathrm{L})$ & $\mathrm{Mg}$ & $P$ \\
\hline & \multirow{4}{*}{ Sauvignon blanc } & 2014 & $103.49 \pm 3.73 \mathrm{a}$ & $126.35 \pm 5.20^{\mathrm{n}}$ & $22.96 \pm 2.90$ hijk & $98.74 \pm 1.11$ opr & $135.69 \pm 8.30^{\mathrm{d}}$ \\
\hline & & 2015 & $110.92 \pm 3.73^{\mathrm{a}}$ & $120.75 \pm 0.74^{\mathrm{n}}$ & $31.41 \pm 1.32$ cdef & $91.81 \pm 3.45^{\mathrm{r}}$ & $135.45 \pm 6.58^{\mathrm{d}}$ \\
\hline & & 2016 & $105.82 \pm 5.91^{\mathrm{a}}$ & $146.90 \pm 5.51^{\mathrm{m}}$ & $30.96 \pm 1.08$ cdef & $95.34 \pm 1.00 \mathrm{pr}$ & $106.37 \pm 1.72$ ghij \\
\hline & & Average & $106.74 \pm 1.12$ & $131.33 \pm 2.67$ & $28.44 \pm 0.99$ & $95.30 \pm 1.38$ & $125.83 \pm 3.42$ \\
\hline & \multirow{4}{*}{ Muscat Ottonel } & 2014 & $82.52 \pm 3.96$ bcd & $294.89 \pm 6.26^{g}$ & $31.11 \pm 10.19$ cdefg & $227.71 \pm 4.16^{\mathrm{a}}$ & $85.90 \pm 10.19 \mathrm{klmn}$ \\
\hline & & 2015 & $92.01 \pm 4.19 \mathrm{~b}$ & $251.89 \pm 16.62 \mathrm{hi}$ & $18.89 \pm 5.86^{\mathrm{jkl}}$ & $206.63 \pm 6.83^{b}$ & $99.81 \pm 2.18^{\text {hijk }}$ \\
\hline & & 2016 & $86.68 \pm 6.92 \mathrm{~b}$ & $212.78 \pm 6.17 \mathrm{kl}$ & $23.24 \pm 6.18^{\text {hijk }}$ & $158.52 \pm 5.96 \mathrm{de}$ & $79.34 \pm 8.60 \mathrm{lmno}$ \\
\hline & & Average & $87.07 \pm 1.65$ & $253.19 \pm 6.01$ & $24.75 \pm 2.41$ & $197.62 \pm 1.37$ & $88.35 \pm 4.24$ \\
\hline & \multirow{4}{*}{ Italian Riesling } & 2014 & $63.08 \pm 5.74 \mathrm{ghi}$ & $225.52 \pm 7.73 \mathrm{jk}$ & $17.78 \pm 4.86 \mathrm{klm}$ & $126.60 \pm 6.79$ hijk & $93.48 \pm 17.16^{\mathrm{ijkl}}$ \\
\hline & & 2015 & $70.34 \pm 2.54$ efg & $224.03 \pm 18.72^{j \mathrm{k}}$ & $21.22 \pm 0.01^{\mathrm{ijk}}$ & $138.43 \pm 5.65 \mathrm{gh}$ & $95.59 \pm 16.71^{\mathrm{ijkl}}$ \\
\hline & & 2016 & $63.45 \pm 5.98 \mathrm{ghi}$ & $201.07 \pm 2.82^{1}$ & $20.70 \pm 0.71^{\mathrm{ijk}}$ & $128.98 \pm 5.46$ hij & $92.93 \pm 10.78^{\mathrm{ijkl}}$ \\
\hline & & Average & $65.62 \pm 1.92$ & $219.88 \pm 8.14$ & $19.90 \pm 2.62$ & $131.33 \pm 0.72$ & $93.33 \pm 3.56$ \\
\hline \multirow{2}{*}{ Sig. } & & & $* * *$ & $* * *$ & $* * *$ & $* * *$ & $* * *$ \\
\hline & & & 58.317 & 312.265 & 18.268 & 82.066 & 10.152 \\
\hline Variety & & & *** & $*^{* * *}$ & *** & $* * *$ & *** \\
\hline Years & & & ** & ns & ns & $* * *$ & ns \\
\hline Variety $\times$ Years & & & * & $* * *$ & $* * *$ & $* * *$ & ** \\
\hline
\end{tabular}

Average value \pm standard deviation $(\mathrm{n}=3$ ). Romans' letters represent the significance of the difference (Duncan test, $\mathrm{p}<0.05)$. The difference between any two values, followed by at least one common letter, is insignificant. MPL = maximal permissible limit (O.I.V., 2016). LOQ = lower than the limit of quantification

Table 3. Determination of trace elements in wines from Dealu Bujorului vineyard by ICP-MS (mg/L); (mean \pm SD)

\begin{tabular}{|c|c|c|c|c|c|c|c|c|}
\hline Area & Variety & Vintage & $\mathrm{Fe}$ & $\mathrm{Cu}(\mathrm{MPL}=1 \mathrm{mg} / \mathrm{L})$ & $\mathrm{Mn}$ & $\mathrm{Zn}(\mathrm{MPL}=5 \mathrm{mg} / \mathrm{L})$ & $\mathrm{L}$ & $\mathrm{Cr}$ \\
\hline \multirow{20}{*}{ 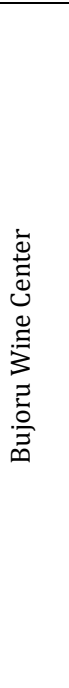 } & \multirow[t]{4}{*}{ Merlot } & 2014 & $10.81 \pm 1.31^{\mathrm{ijkl}}$ & $0.70 \pm 0.07 \mathrm{abcd}$ & $0.16 \pm 0.07 \mathrm{jkl}$ & $1.11 \pm 0.13 \mathrm{jkmo}$ & $10.66 \pm 1.35$ hij & $0.41 \pm 0.24^{\mathrm{ijkl}}$ \\
\hline & & 2016 & $13.56 \pm 0.58^{\text {cdefghi }}$ & $0.70 \pm 0.17$ abcd & $0.21 \pm 0.02$ hijkl & $1.19 \pm 0.06^{\mathrm{jklmn}}$ & $11.93 \pm 0.61$ efghi & $0.56 \pm 0.11$ efghijkl \\
\hline & & 2018 & $11.52 \pm 0.72$ efghij & $0.62 \pm 0.22$ abcde & $0.20 \pm 0.07 \mathrm{ijkl}$ & $1.03 \pm 0.07$ Imnop & $11.34 \pm 1.69 \mathrm{ghi}$ & $0.57 \pm 0.11$ efghijkl \\
\hline & & Average & $11.96 \pm 0.39$ & $0.68 \pm 0.08$ & $0.19 \pm 0.03$ & $1.11 \pm 0.04$ & $11.31 \pm 0.55$ & $0.54 \pm 0.08$ \\
\hline & \multirow{4}{*}{$\begin{array}{l}\text { Cabernet } \\
\text { Sauvignon }\end{array}$} & 2014 & $12.90 \pm 1.53$ defghi & $0.44 \pm 0.11$ defghijk & $0.16 \pm 0.06 \mathrm{jkl}$ & $0.80 \pm 0.17$ nopqr & $12.63 \pm 1.57$ defgh & $0.44 \pm 0.02^{\text {hijkl }}$ \\
\hline & & 2015 & $14.56 \pm 4.05 \mathrm{cdef}$ & $0.49 \pm 0.06$ bcdefghijk & $0.23 \pm 0.11^{\text {hijkl }}$ & $0.88 \pm 0.10 \mathrm{mnopq}$ & $12.52 \pm 1.63$ defgh & $0.54 \pm 0.11$ efghijkl \\
\hline & & 2016 & $13.27 \pm 0.95$ cdefghi & $0.51 \pm 0.22$ bcdefghij & $0.20 \pm 0.06^{\mathrm{ijkl}}$ & $0.51 \pm 0.17$ qrs & $10.70 \pm 0.71^{\mathrm{ijk}}$ & $0.37 \pm 0.12^{\mathrm{jkl}}$ \\
\hline & & Average & $13.57 \pm 1.65$ & $0.48 \pm 0.08$ & $0.20 \pm 0.03$ & $0.77 \pm 0.04$ & $11.95 \pm 0.51$ & $0.45 \pm 0.06$ \\
\hline & \multirow[t]{4}{*}{ Feteasca neagră } & 2014 & $16.26 \pm 2.01 \mathrm{abc}$ & $0.45 \pm 0.11$ cdefghijk & $0.43 \pm 0.04$ bcde & $3.11 \pm 0.19 \mathrm{~b}$ & $9.15 \pm 1.28^{\mathrm{jkl}}$ & $0.66 \pm 0.06$ efghij \\
\hline & & 2015 & $13.93 \pm 1.47$ cdefgh & $0.24 \pm 0.02 \mathrm{jk}$ & $0.42 \pm 0.05$ bcdef & $3.30 \pm 0.13 \mathrm{ab}$ & $7.78 \pm 2.06 \mathrm{jklm}$ & $0.69 \pm 0.06$ abcd \\
\hline & & 2016 & $15.63 \pm 1.22 \mathrm{bcd}$ & $0.29 \pm 0.06$ ghijk & $0.30 \pm 0.06$ defghij & $3.59 \pm 0.56^{\mathrm{a}}$ & $8.70 \pm 1.04 \mathrm{ijkl}$ & $0.69 \pm 0.05$ abcde \\
\hline & & Average & $15.28 \pm 0.40$ & $0.32 \pm 0.03$ & $0.38 \pm 0.01$ & $3.33 \pm 0.23$ & $8.54 \pm 0.53$ & $0.68 \pm 0.03$ \\
\hline & \multirow[t]{4}{*}{ Burgund Mare } & 2016 & $13.23 \pm 1.01$ cdefghi & $0.56 \pm 0.11$ bcdefgh & $0.18 \pm 0.04^{\mathrm{jkl}}$ & $2.23 \pm 0.10^{c}$ & $6.55 \pm 1.06 \mathrm{klm}$ & $0.47 \pm 0.06^{\text {ghijkl }}$ \\
\hline & & 2017 & $10.74 \pm 1.21^{\mathrm{ijkl}}$ & $0.57 \pm 0.02$ bcdefg & $0.17 \pm 0.05 \mathrm{jkl}$ & $2.03 \pm 0.07$ cde & $7.44 \pm 1.99 \mathrm{klm}$ & $0.62 \pm 0.06$ efghijk \\
\hline & & 2018 & $13.27 \pm 0.95$ cdefghi & $0.61 \pm 0.15$ abcdef & $0.20 \pm 0.02^{\mathrm{ijkl}}$ & $1.99 \pm 0.11$ dcef & $6.76 \pm 2.15 \mathrm{klm}$ & $0.59 \pm 0.06$ efghijkl \\
\hline & & Average & $12.41 \pm 0.14$ & $0.58 \pm 0.07$ & $0.18 \pm 0.01$ & $2.09 \pm 0.02$ & $6.92 \pm 0.59$ & $0.56 \pm 0.01$ \\
\hline & \multirow[t]{4}{*}{ Băbeasca neagră } & 2015 & $9.63 \pm 0.44 \mathrm{kl}$ & $0.28 \pm 0.05$ hijk & $0.11 \pm 0.02^{1}$ & $1.33 \pm 0.10^{\mathrm{ijk} k \mathrm{~m}}$ & $14.86 \pm 1.48$ bcdef & $0.73 \pm 0.07$ efgh \\
\hline & & 2016 & $10.74 \pm 1.20^{\mathrm{ijkl}}$ & $0.33 \pm 0.10^{\text {fghijk }}$ & $0.16 \pm 0.05 \mathrm{jkl}$ & $1.40 \pm 0.17$ hijkl & $15.78 \pm 1.79$ bcd & $0.59 \pm 0.16^{\text {efghijkl }}$ \\
\hline & & 2017 & $12.25 \pm 0.97$ efghij & $0.37 \pm 0.07$ efghijk & $0.16 \pm 0.05 \mathrm{jkl}$ & $1.48 \pm 0.44$ ghijkl & $15.60 \pm 0.64$ bcd & $0.51 \pm 0.17^{\text {fghijkl }}$ \\
\hline & & Average & $10.87 \pm 0.39$ & $0.33 \pm 0.03$ & $0.14 \pm 0.02$ & $1.41 \pm 0.18$ & $15.41 \pm 0.60$ & $0.61 \pm 0.06$ \\
\hline
\end{tabular}

Bulletin of University of Agricultural Sciences and Veterinary Medicine Cluj-Napoca. Horticulture 


\begin{tabular}{|c|c|c|c|c|c|c|c|c|}
\hline Area & Variety & Vintage & $\mathrm{Fe}$ & $\mathrm{Cu}(\mathrm{MPL}=1 \mathrm{mg} / \mathrm{L})$ & $\mathrm{Mn}$ & Zn (MPL=5 mg/L) & $\mathrm{L}$ & $\mathrm{Cr}$ \\
\hline & Feteasca regală & 2015 & $9.44 \pm 0.69^{1}$ & $0.44 \pm 0.11$ defghijk & $0.63 \pm 0.12^{a}$ & $0.37 \pm 0.12 \mathrm{rs}$ & $4.57 \pm 0.58^{\mathrm{m}}$ & $0.81 \pm 0.16^{\text {cdef }}$ \\
\hline & & 2016 & $11.37 \pm 1.55$ ghijkl & $0.87 \pm 0.11^{\mathrm{a}}$ & $0.52 \pm 0.15 \mathrm{abc}$ & $0.51 \pm 0.23$ qrs & $5.62 \pm 0.68 \mathrm{Im}$ & $0.73 \pm 0.11 \mathrm{abc}$ \\
\hline & & 2017 & $11.80 \pm 0.72$ fghijkl & $0.70 \pm 0.33$ abcd & $0.61 \pm 0.16^{\mathrm{a}}$ & $0.64 \pm 0.09$ pqrs & $4.90 \pm 0.58^{\mathrm{m}}$ & $0.80 \pm 0.12$ cdef \\
\hline & & Average & $10.87 \pm 0.49$ & $0.67 \pm 0.13$ & $0.59 \pm 0.02$ & $0.51 \pm 0.07$ & $5.06 \pm 0.06$ & $0.78 \pm 0.03$ \\
\hline & Feteasca albă & 2015 & $11.92 \pm 1.54$ fghijkl & $0.47 \pm 0.06$ cdefghijk & $0.16 \pm 0.06^{\mathrm{jkl}}$ & $2.93 \pm 0.51^{b}$ & $12.86 \pm 1.19$ defgh & $0.84 \pm 0.16^{\text {bcde }}$ \\
\hline & & 2016 & $10.55 \pm 0.97 \mathrm{jkl}$ & $0.73 \pm 0.24 \mathrm{abc}$ & $0.28 \pm 0.06_{\text {fghijk }}$ & $2.07 \pm 0.08 \mathrm{~cd}$ & $11.90 \pm 1.53$ efghi & $0.51 \pm 0.06^{\text {fghijkl }}$ \\
\hline & & 2018 & $14.23 \pm 1.01^{\text {cdefg }}$ & $0.71 \pm 0.05 \mathrm{abcd}$ & $0.21 \pm 0.02$ hijkl & $1.11 \pm 0.29 \mathrm{klmno}$ & $13.92 \pm 0.54$ cdefgh & $0.65 \pm 0.11$ efghij \\
\hline & & Average & $12.23 \pm 0.32$ & $0.64 \pm 0.11$ & $0.22 \pm 0.02$ & $2.04 \pm 0.22$ & $12.89 \pm 0.50$ & $0.67 \pm 0.05$ \\
\hline & Băbeasca gri & 2014 & $20.78 \pm 0.77 \mathrm{a}$ & $0.51 \pm 0.16$ bcdefghij & $0.36 \pm 0.08$ defgh & $0.25 \pm 0.07 \mathrm{~s}$ & $14.63 \pm 2.04$ cdefg & $0.50 \pm 0.06^{\text {fghijkl }}$ \\
\hline & & 2015 & $19.18 \pm 2.47 \mathrm{a}$ & $0.55 \pm 0.18$ bcdefgh & $0.55 \pm 0.11 \mathrm{ab}$ & $0.33 \pm 0.11^{\mathrm{s}}$ & $18.26 \pm 2.95 \mathrm{ab}$ & $0.61 \pm 0.13$ efghijkl \\
\hline & & 2016 & $18.78 \pm 2.83^{a}$ & $0.17 \pm 0.02 \mathrm{k}$ & $0.34 \pm 0.10$ defghi & $0.23 \pm 0.11^{s}$ & $16.90 \pm 3.78 \mathrm{abc}$ & $0.62 \pm 0.07$ efghijk \\
\hline & & Average & $19.58 \pm 1.10$ & $0.59 \pm 0.01$ & $0.41 \pm 0.01$ & $0.27 \pm 0.02$ & $16.60 \pm 0.87$ & $0.58 \pm 0.04$ \\
\hline & Șarba & 2014 & $14.56 \pm 3.21$ cdef & $0.77 \pm 0.22 \mathrm{ab}$ & $0.55 \pm 0.11 \mathrm{ab}$ & $1.58 \pm 0.63$ efghij & $12.56 \pm 1.53$ defgh & $0.62 \pm 0.16$ efghijkl \\
\hline & & 2015 & $18.02 \pm 0.35$ ab & $0.59 \pm 0.12$ bcdef & $0.39 \pm 0.05_{\text {cdefg }}$ & $1.56 \pm 0.49$ fghijk & $15.23 \pm 1.00$ bcde & $0.77 \pm 0.18$ defg \\
\hline & & 2016 & $18.74 \pm 2.50^{a}$ & $0.45 \pm 0.18$ cdefghijk & $0.44 \pm 0.12$ bcd & $1.82 \pm 0.51$ cdefgh & $11.52 \pm 0.72^{\text {fghi }}$ & $0.73 \pm 0.06^{\text {efgh }}$ \\
\hline & & Average & $17.11 \pm 1.49$ & $0.60 \pm 0.05$ & $0.46 \pm 0.03$ & $1.66 \pm 0.07$ & $13.10 \pm 0.41$ & $0.71 \pm 0.06$ \\
\hline & Aligoté & 2014 & $10.46 \pm 0.68 \mathrm{jkl}$ & $0.51 \pm 0.12$ bcdefghij & $0.30 \pm 0.13$ efghij & $1.93 \pm 0.28 \mathrm{cdefg}$ & $14.89 \pm 0.58$ bcdef & $1.07 \pm 0.13 \mathrm{bc}$ \\
\hline & & 2015 & $14.93 \pm 3.52$ cde & $0.65 \pm 0.18$ abcde & $0.28 \pm 0.06^{\text {fghijk }}$ & $2.12 \pm 0.01^{\mathrm{cd}}$ & $11.52 \pm 0.72$ fghi & $1.11 \pm 0.11^{\mathrm{b}}$ \\
\hline & & 2016 & $14.23 \pm 1.00$ cdefg & $0.69 \pm 0.22$ abcd & $0.16 \pm 0.05 \mathrm{jkl}$ & $1.37 \pm 0.13$ hijkl & $14.60 \pm 0.64$ cdefg & $1.06 \pm 0.13$ bcd \\
\hline & & Average & $13.21 \pm 1.56$ & $0.62 \pm 0.05$ & $0.25 \pm 0.04$ & $1.81 \pm 0.14$ & $13.67 \pm 0.07$ & $1.08 \pm 0.01$ \\
\hline & Sauvignon blanc & 2014 & $10.56 \pm 1.42 \mathrm{jkl}$ & $0.77 \pm 0.10 \mathrm{ab}$ & $0.25 \pm 0.08$ ghijkl & $1.29 \pm 0.06 \mathrm{ijklm}$ & $16.56 \pm 4.16 \mathrm{abc}$ & $0.36 \pm 0.06^{\mathrm{jkl}}$ \\
\hline & & 2015 & $11.90 \pm 1.15$ fghijkl & $0.70 \pm 0.06$ abcd & $0.13 \pm 0.05 \mathrm{kl}$ & $1.69 \pm 0.33$ defghi & $15.93 \pm 1.23 \mathrm{bcd}$ & $0.32 \pm 0.12^{\mathrm{kl}}$ \\
\hline & & 2016 & $10.89 \pm 1.43^{\mathrm{ijkl}}$ & $0.52 \pm 0.16$ bcdefghi & $0.18 \pm 0.05 \mathrm{jkl}$ & $1.26 \pm 0.06 \mathrm{ijkmn}$ & $19.23 \pm 2.00^{a}$ & $0.31 \pm 0.11^{1}$ \\
\hline & & Average & $11.12 \pm 0.16$ & $0.66 \pm 0.05$ & $0.19 \pm 0.02$ & $1.41 \pm 0.15$ & $17.24 \pm 1.52$ & $0.33 \pm 0.03$ \\
\hline & Muscat Ottonel & 2014 & $13.26 \pm 0.95$ cdefghi & $0.21 \pm 0.03 \mathrm{k}$ & $0.18 \pm 0.05 \mathrm{jkl}$ & $0.43 \pm 0.11$ qrs & $14.27 \pm 1.95^{\text {cdefg }}$ & $0.84 \pm 0.16$ bcde \\
\hline & & 2015 & $9.66 \pm 0.72 \mathrm{kl}$ & $0.26 \pm 0.16^{\mathrm{ijk}}$ & $0.26 \pm 0.07$ ghijk & $0.66 \pm 0.12$ opqrs & $14.56 \pm 0.58^{\text {cdefg }}$ & $1.40 \pm 0.52^{\mathrm{a}}$ \\
\hline & & 2016 & $12.86 \pm 1.19$ efghijkl & $0.34 \pm 0.11^{\text {fghijk }}$ & $0.19 \pm 0.03$ ijkl & $1.10 \pm 0.13 \mathrm{klmno}$ & $15.56 \pm 2.31 \mathrm{bcd}$ & $1.03 \pm 0.17$ bcd \\
\hline & & Average & $11.93 \pm 0.23$ & $0.37 \pm 0.07$ & $0.21 \pm 0.02$ & $0.73 \pm 0.01$ & $14.80 \pm 0.91$ & $1.09 \pm 0.20$ \\
\hline & Italian Riesling & 2014 & $12.23 \pm 2.00$ cdefghi & $0.33 \pm 0.11^{\text {fghijk }}$ & $0.25 \pm 0.06^{\text {ghijkl }}$ & $2.03 \pm 0.17$ cde & $13.58 \pm 1.18$ cdefgh & $0.51 \pm 0.24$ fghijkl \\
\hline & & 2015 & $11.11 \pm 1.83$ hijkl & $0.40 \pm 0.05$ defghijk & $0.33 \pm 0.11$ defghi & $2.00 \pm 0.12$ cde & $16.56 \pm 4.04 \mathrm{abc}$ & $0.50 \pm 0.12$ fghijkl \\
\hline & & 2016 & $13.34 \pm 1.17$ cdefhi & $0.40 \pm 0.07$ defghijk & $0.28 \pm 0.05_{\text {fghijk }}$ & $1.37 \pm 0.16^{\text {hijkl }}$ & $13.56 \pm 0.58$ cdefgh & $0.77 \pm 0.29$ defg \\
\hline & & Average & $12.23 \pm 0.44$ & $0.37 \pm 0.03$ & $0.29 \pm 0.03$ & $1.80 \pm 0.03$ & $14.57 \pm 1.85$ & $0.60 \pm 0.09$ \\
\hline \multirow[t]{2}{*}{ Sig. } & & & $* * *$ & $* * *$ & $* * *$ & $* * *$ & $* * *$ & $* * *$ \\
\hline & & & 8.882 & 4.357 & 10.152 & 34.616 & 13.519 & 6.826 \\
\hline Variety & & & $* * *$ & $* * *$ & $* * *$ & $* * *$ & $* * *$ & $* * *$ \\
\hline Years & & & * & ns & ns & * & ns & ns \\
\hline Variety $\times$ Years & & & $* *$ & ns & * & $* * *$ & ns & $*$ \\
\hline
\end{tabular}

Average value \pm standard deviation $(\mathrm{n}=3$ ). Romans' letters represent the significance of the difference (Duncan test, $\mathrm{p}<0.05)$. The difference between any two values, followed by at least one common letter, is insignificant. MPL = maximal permissible limit (O.I.V., 2016). LOQ = lower than the limit of quantification 
Table 4. Determination of heavy elements found in wines from Dealu Bujorului vineyard by ICP-MS $(\mu \mathrm{g} / \mathrm{L}$ (mean \pm SD)

\begin{tabular}{|c|c|c|c|c|c|c|c|c|}
\hline Area & Variety & Vintage & $\mathrm{Cd}(\mathrm{MPL}=0.01 \mathrm{mg} / \mathrm{L})$ & $\mathrm{Pb}(\mathrm{MPL}=0.15 \mathrm{mg} / \mathrm{L})$ & Co & As (MPL $=0.2 \mathrm{mg} / \mathrm{L})$ & $\mathrm{Hg}$ & $\mathrm{U}$ \\
\hline \multirow{40}{*}{ 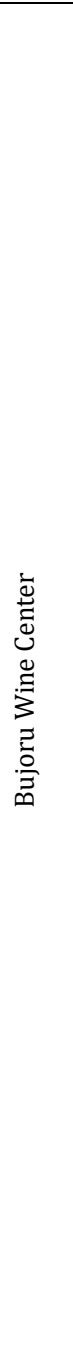 } & \multirow[t]{4}{*}{ Merlot } & 2014 & $0.22 \pm 0.10$ efghijk & $24.22 \pm 7.00^{\mathrm{Imno}}$ & $2.90 \pm 1.52$ hijk & $9.89 \pm 3.03$ efghijk & $0.20 \pm 0.03$ def & $0.15 \pm 0.07$ cdefg \\
\hline & & 2016 & $0.15 \pm 0.06$ ghijklm & $20.81 \pm 0.80 \mathrm{mno}$ & $4.93 \pm 0.61$ defghi & $7.10 \pm 2.45 \mathrm{ijklmn}$ & $0.20 \pm 0.02$ def & $0.16 \pm 0.03$ cdefg \\
\hline & & 2018 & $0.15 \pm 0.03$ ghijklm & $20.73 \pm 2.39 \mathrm{mno}$ & $5.23 \pm 1.00$ defgh & $13.70 \pm 4.50 \mathrm{abcd}$ & $0.13 \pm 0.04$ ef & $0.13 \pm 0.02$ efg \\
\hline & & Average & $0.17 \pm 0.03$ & $21.92 \pm 3.22$ & $4.35 \pm 0.46$ & $10.23 \pm 1.06$ & $0.18 \pm 0.01$ & $0.15 \pm 0.02$ \\
\hline & \multirow{4}{*}{$\begin{array}{l}\text { Cabernet } \\
\text { Sauvignon }\end{array}$} & 2014 & $0.10 \pm 0.02 \mathrm{klm}$ & $41.85 \pm 1.80^{\text {hijk }}$ & $4.17 \pm 0.85$ efghi & $12.45 \pm 1.07$ bcdef & ULD & $0.12 \pm 0.03$ efg \\
\hline & & 2015 & $0.16 \pm 0.07$ ghijklm & $54.77 \pm 9.966^{\text {efgh }}$ & $3.17 \pm 0.18^{\text {hijk }}$ & $10.70 \pm 1.61^{\text {cdefghi }}$ & ULD & $0.16 \pm 0.02$ cdefg \\
\hline & & 2016 & $0.22 \pm 0.10$ efghijk & $37.04 \pm 6.41^{\mathrm{i} j \mathrm{kl}}$ & $2.81 \pm 0.47 \mathrm{ijk}$ & $11.39 \pm 0.52$ bcdefgh & $0.17 \pm 0.05$ ef & $0.13 \pm 0.02$ efg \\
\hline & & Average & $0.16 \pm 0.04$ & $44.55 \pm 4.09$ & $3.38 \pm 0.34$ & $11.51 \pm 0.54$ & - & $0.14 \pm 0.01$ \\
\hline & \multirow[t]{4}{*}{ Feteasca neagră } & 2014 & $0.33 \pm 0.11$ bcde & $13.56 \pm 1.48^{\circ}$ & $10.74 \pm 1.84^{c}$ & $4.27 \pm 1.06 \mathrm{mno}$ & $0.20 \pm 0.01$ def & $0.16 \pm 0.05^{\text {cdefg }}$ \\
\hline & & 2015 & $0.39 \pm 0.08 \mathrm{abc}$ & $19.96 \pm 1.22 \mathrm{mno}$ & $10.75 \pm 1.20^{c}$ & $3.64 \pm 1.47$ no & $0.24 \pm 0.07$ bcde & $0.21 \pm 0.01$ abcdef \\
\hline & & 2016 & $0.27 \pm 0.05$ cdefg & $14.23 \pm 1.01^{\circ}$ & $12.04 \pm 0.71^{\mathrm{c}}$ & $4.94 \pm 1.13 \mathrm{Imno}$ & $0.18 \pm 0.04$ ef & $0.17 \pm 0.02$ cdefg \\
\hline & & Average & $0.33 \pm 0.03$ & $15.95 \pm 0.24$ & $11.18 \pm 0.56$ & $4.28 \pm 0.22$ & $0.20 \pm 0.03$ & $0.18 \pm 0.02$ \\
\hline & \multirow[t]{4}{*}{ Burgund Mare } & 2016 & $0.14 \pm 0.07$ ghijklm & $48.45 \pm 5.18$ fghi & $4.48 \pm 1.12$ efghi & $2.96 \pm 2.03^{\circ}$ & $0.25 \pm 0.15$ bcde & $0.16 \pm 0.03$ cdefg \\
\hline & & 2017 & $0.11 \pm 0.01 \mathrm{jklm}$ & $35.52 \pm 7.23^{\mathrm{ijkl}}$ & $4.31 \pm 1.12$ efghi & $6.78 \pm 2.87 \mathrm{jklmn}$ & $0.12 \pm 0.09 \mathrm{fg}$ & $0.23 \pm 0.03$ abcd \\
\hline & & 2018 & $0.12 \pm 0.01 \mathrm{jklm}$ & $41.97 \pm 2.18^{\text {hijk }}$ & $4.60 \pm 0.64$ efghi & $8.54 \pm 1.63$ ghijkl & $0.17 \pm 0.06$ ef & $0.18 \pm 0.01$ bcdefg \\
\hline & & Average & $0.12 \pm 0.03$ & $41.98 \pm 2.54$ & $4.46 \pm 0.38$ & $6.10 \pm 0.64$ & $0.18 \pm 0.05$ & $0.19 \pm 0.01$ \\
\hline & \multirow[t]{4}{*}{ Băbeasca neagră } & 2015 & $0.48 \pm 0.12^{a}$ & $124.48 \pm 6.83^{a}$ & $4.28 \pm 1.03$ efghi & $10.03 \pm 0.25$ defghijk & $0.23 \pm 0.12^{\text {cdef }}$ & $0.16 \pm 0.05$ cdefg \\
\hline & & 2016 & $0.40 \pm 0.06 \mathrm{ab}$ & $121.49 \pm 10.15^{a}$ & $3.56 \pm 0.58$ ghijk & $12.14 \pm 2.18$ bcdefg & $0.25 \pm 0.08$ bcde & $0.16 . \pm 0.05$ cdefg \\
\hline & & 2017 & $0.26 \pm 0.07^{\text {cdefghi }}$ & $115.82 \pm 6.62^{a}$ & $3.81 \pm 0.52^{\text {fghij }}$ & $11.81 \pm 1.23$ bcdefg & ULD & $0.24 \pm 0.06$ abc \\
\hline & & Average & $0.38 \pm 0.03$ & $120.93 \pm 1.98$ & $3.89 \pm 0.28$ & $11.33 \pm 0.96$ & $0.16 \pm 0.06$ & $0.19 \pm 0.01$ \\
\hline & \multirow[t]{4}{*}{ Feteasca regală } & 2015 & $0.25 \pm 0.11$ defghi & $55.41 \pm 9.95$ efg & $20.70 \pm 1.61^{a}$ & $6.06 \pm 1.56 \mathrm{Imno}$ & $0.35 \pm 0.12 \mathrm{abc}$ & $0.13 \pm 0.02$ efg \\
\hline & & 2016 & $0.27 \pm 0.02$ cdefgh & $40.53 \pm 7.30^{\mathrm{ijk}}$ & $21.05 \pm 0.22$ a & $7.62 \pm 1.32 \mathrm{ijklm}$ & $0.39 \pm 0.02^{\mathrm{a}}$ & $0.17 \pm 0.05$ cdefg \\
\hline & & 2017 & $0.30 \pm 0.07$ bcdef & $42.12 \pm 1.93$ ghijk & $18.46 \pm 0.74 \mathrm{~b}$ & $7.03 \pm 0.78 \mathrm{ijklmn}$ & $0.35 \pm 0.08 \mathrm{abc}$ & $0.19 \pm 0.10$ abcdefg \\
\hline & & Average & $0.27 \pm 0.05$ & $46.02 \pm 4.08$ & $20.07 \pm 0.70$ & $6.91 \pm 0.40$ & $0.37 \pm 0.05$ & $0.16 \pm 0.04$ \\
\hline & \multirow[t]{4}{*}{ Feteasca albă } & 2015 & $0.14 \pm 0.07$ hijklm & $14.78 \pm 2.87^{\circ}$ & $4.18 \pm 1.47$ efghi & $14.18 \pm 2.83 \mathrm{abc}$ & ULD & $0.14 \pm 0.03$ defg \\
\hline & & 2016 & $0.12 \pm 0.02 \mathrm{jklm}$ & $10.25 \pm 0.64^{\circ}$ & $3.95 \pm 1.47^{\text {fghij }}$ & $16.26 \pm 3.37^{\mathrm{a}}$ & ULD & $0.14 \pm 0.03$ defg \\
\hline & & 2018 & $0.14 \pm 0.05$ hijklm & $16.49 \pm 6.86^{\text {no }}$ & $4.48 \pm 2.22$ efghi & $14.86 \pm 2.81^{\mathrm{ab}}$ & ULD & $0.20 \pm 0.08$ abcdefg \\
\hline & & Average & $0.13 \pm 0.03$ & $13.84 \pm 3.15$ & $4.20 \pm 0.70$ & $15.10 \pm 0.32$ & - & $0.16 \pm 0.03$ \\
\hline & \multirow[t]{4}{*}{ Băbeasca gri } & 2014 & $0.36 \pm 0.06$ abcd & $30.06 \pm 7.00 \mathrm{klmn}$ & $1.51 \pm 0.71^{\mathrm{k}}$ & $8.00 \pm 1.81$ efghijk & $0.21 \pm 0.08$ def & $0.11 \pm 0.02 \mathrm{~g}$ \\
\hline & & 2015 & $0.27 \pm 0.05$ cdefg & $21.50 \pm 2.75 \mathrm{mno}$ & $1.43 \pm 0.59 \mathrm{k}$ & $13.05 \pm 1.05$ abcde & $0.21 \pm 0.02$ def & $0.14 \pm 0.03$ defg \\
\hline & & 2016 & $0.33 \pm 0.11$ bcde & $31.45 \pm 5.30 \mathrm{jklm}$ & $1.40 \pm 0.16^{k}$ & $11.52 \pm 0.72$ bcdefgh & $0.36 \pm 0.11 \mathrm{ab}$ & $0.13 \pm 0.02$ efg \\
\hline & & Average & $0.32 \pm 0.03$ & $27.67 \pm 2.14$ & $1.45 \pm 0.29$ & $10.85 \pm 0.55$ & $0.26 \pm 0.05$ & $0.12 \pm 0.01$ \\
\hline & \multirow[t]{4}{*}{ Șarba } & 2014 & $0.08 \pm 0.05^{\mathrm{m}}$ & $78.95 \pm 10.95^{c}$ & $7.07 \pm 1.78^{d}$ & $5.75 \pm 1.58 \mathrm{Imno}$ & $0.36 \pm 0.09 \mathrm{ab}$ & $0.21 \pm 0.02$ abcdef \\
\hline & & 2015 & $0.12 \pm 0.05 \mathrm{jklm}$ & $66.73 \pm 9.34$ cde & $6.34 \pm 1.15 \mathrm{de}$ & $6.79 \pm 1.70 \mathrm{jklmn}$ & $0.35 \pm 0.11 \mathrm{abc}$ & $0.28 \pm 0.06^{\mathrm{a}}$ \\
\hline & & 2016 & $0.08 \pm 0.05 \mathrm{~lm}$ & $70.66 \pm 12.11^{\text {cd }}$ & $3.14 \pm 1.13 \mathrm{k}$ & $6.01 \pm 0.58 \mathrm{Imno}$ & $0.31 \pm 0.06$ abcd & $0.25 \pm 0.06$ abc \\
\hline & & Average & $0.09 \pm 0.03$ & $72.11 \pm 1.39$ & $5.52 \pm 0.37$ & $6.18 \pm 0.61$ & $0.34 \pm 0.02$ & $0.25 \pm 0.02$ \\
\hline & \multirow[t]{4}{*}{ Aligoté } & 2014 & $0.26 \pm 0.06^{\text {cdefghi }}$ & $35.85 \pm 3.81^{\mathrm{i} j \mathrm{kl}}$ & $5.93 \pm 2.57 \mathrm{def}$ & $6.58 \pm 2.07 \mathrm{klmno}$ & $0.15 \pm 0.07$ ef & $0.17 \pm 0.03$ cdefg \\
\hline & & 2015 & $0.36 \pm 0.12$ abcd & $21.52 \pm 1.80 \mathrm{mno}$ & $5.22 \pm 1.00$ defgh & $10.37 \pm 4.11$ defghij & $0.16 \pm 0.03$ ef & $0.11 \pm 0.02 \mathrm{~g}$ \\
\hline & & 2016 & $0.33 \pm 0.05$ bcde & $45.44 \pm 7.90$ ghij & $5.67 \pm 1.39$ defg & $12.28 \pm 1.72$ bcdef & $0.19 \pm 0.05$ def & $0.16 \pm 0.02$ cdefg \\
\hline & & Average & $0.32 \pm 0.04$ & $34.27 \pm 3.11$ & $5.61 \pm 0.82$ & $9.75 \pm 1.29$ & $0.17 \pm 0.02$ & $0.15 \pm 0.01$ \\
\hline
\end{tabular}




\begin{tabular}{|c|c|c|c|c|c|c|c|c|}
\hline Area & Variety & Vintage & Cd (MPL=0.01 mg/L) & $\mathrm{Pb}(\mathrm{MPL}=0.15 \mathrm{mg} / \mathrm{L})$ & Co & As (MPL $=0.2 \mathrm{mg} / \mathrm{L}$ ) & $\mathrm{Hg}$ & $\mathrm{U}$ \\
\hline & Sauvignon blanc & 2014 & $0.21 \pm 0.02$ efghijk & $59.66 \pm 17.99$ def & $4.23 \pm 1.01$ efghi & $7.88 \pm 1.36$ hijklm & $0.19 \pm 0.03$ def & $0.21 \pm 0.11$ abcdef \\
\hline & & 2015 & $0.29 \pm 0.06$ bcdef & $62.44 \pm 14.02 \mathrm{de}$ & $4.23 \pm 1.01^{\text {efghi }}$ & $5.34 \pm 1.73^{\mathrm{Imno}}$ & $0.20 \pm 0.04$ def & $0.20 \pm 0.02$ abcdefg \\
\hline & & 2016 & $0.20 \pm 0.02$ fghijklm & $58.97 \pm 16.17$ def & $1.84 \pm 0.53 \mathrm{jk}$ & $8.74 \pm 1.33$ fghijkl & ULD & $0.22 \pm 0.08$ abcde \\
\hline & & Average & $0.23 \pm 0.02$ & $60.36 \pm 1.98$ & $3.43 \pm 0.27$ & $7.32 \pm 0.23$ & $0.13 \pm 0.02$ & $0.21 \pm 0.04$ \\
\hline & Muscat Ottonel & 2014 & $0.21 \pm 0.03$ efghijkl & $29.65 \pm 5.60 \mathrm{klmn}$ & $6.99 \pm 2.35^{\mathrm{d}}$ & $13.56 \pm 1.16$ abcde & $0.18 \pm 0.03$ ef & $0.21 \pm 0.02$ abcdef \\
\hline & & 2015 & $0.15 \pm 0.07$ ghijklm & $40.69 \pm 2.33^{\mathrm{ijk}}$ & $5.23 \pm 1.00$ defgh & $13.19 \pm 1.06$ abcde & $0.18 \pm 0.06$ ef & $0.16 \pm 0.04$ cdefg \\
\hline & & 2016 & $0.29 \pm 0.06$ bcdef & $41.48 \pm 1.64$ ghijk & $4.56 \pm 0.58$ efghi & $14.22 \pm 0.91 \mathrm{abc}$ & $0.21 \pm 0.02$ def & $0.14 \pm 0.03$ defg \\
\hline & & Average & $0.22 \pm 0.02$ & $37.27 \pm 2.11$ & $5.59 \pm 0.92$ & $13.66 \pm 0.09$ & $0.19 \pm 0.02$ & $0.17 \pm 0.01$ \\
\hline & Italian Riesling & 2014 & $0.21 \pm 0.02$ efghijk & $103.07 \pm 4.78^{b}$ & $3.27 \pm 0.95^{\text {hijk }}$ & $4.97 \pm 1.43^{\mathrm{Imno}}$ & $0.18 \pm 0.03$ ef & $0.28 \pm 0.06^{a}$ \\
\hline & & 2015 & $0.10 \pm 0.02 \mathrm{klm}$ & $101.89 \pm 2.51^{\mathrm{b}}$ & $3.93 \pm 0.61^{\text {fghij }}$ & $6.01 \pm 0.50 \mathrm{Imno}$ & $0.16 \pm 0.05$ ef & $0.16 \pm 0.05$ cdefg \\
\hline & & 2016 & $0.25 \pm 0.06$ defghi & $103.13 \pm 5.38^{\mathrm{b}}$ & $1.71 \pm 0.55 \mathrm{jk}$ & $5.64 \pm 0.52 \mathrm{Imno}$ & $0.42 \pm 0.07 \mathrm{a}$ & $0.22 \pm 0.11$ abcde \\
\hline & & Average & $0.15 \pm 0.02$ & $102.70 \pm 1.51$ & $2.97 \pm 0.21$ & $5.54 \pm 0.53$ & $0.25 \pm 0.02$ & $0.22 \pm 0.03$ \\
\hline \multirow[t]{2}{*}{ Sig. } & & & $* * *$ & $* * *$ & $* * *$ & $* * *$ & $* * *$ & $* * *$ \\
\hline & & & 7.082 & 57.440 & 50.502 & 10.344 & 10.535 & 2.515 \\
\hline Variety & & & **** & *** & **** & **** & *** & *** \\
\hline Years & & & ns & ns & ** & $* * *$ & ns & ns \\
\hline Variety $\times$ Years & & & $* *$ & $* *$ & $* *$ & $* *$ & $* * *$ & ns \\
\hline
\end{tabular}

Average value \pm standard deviation $(\mathrm{n}=3$ ). Romans' letters represent the significance of the difference (Duncan test, $\mathrm{p}<0.05)$. The difference between any two values, followed by at least one common letter, is insignificant. M.P.L = maximal permissible limit (O.I.V., 2016). LOQ = lower than the limit of quantification.

Table 5. Determination of macroelements found in soil from Dealu Bujorului vineyard by ICP-MS (mg/kg); (mean \pm SD))

\begin{tabular}{|c|c|c|c|c|c|}
\hline Soil sample & $\mathrm{Ca}$ & $\mathrm{K}$ & $\mathrm{Na}$ & $\mathrm{Mg}$ & $\mathrm{P}$ \\
\hline 1 & $136.13 \pm 12.07 \mathrm{~b}$ & $734.10 \pm 14.37^{d}$ & $123.80 \pm 9.23 b$ & $45.73 \pm 2.51$ de & $74.09 \pm 4.61^{b}$ \\
\hline 2 & $111.94 \pm 13.37 \mathrm{c}$ & $540.76 \pm 2.11^{f}$ & $169.76 \pm 4.43^{a}$ & $39.83 \pm 4.03 \mathrm{e}$ & $62.25 \pm 14.39 \mathrm{bc}$ \\
\hline 3 & $116.13 \pm 13.98^{c}$ & $475.75 \pm 8.50 \mathrm{~g}$ & $108.23 \pm 1.63 \mathrm{bc}$ & $53.86 \pm 2.57 \mathrm{~cd}$ & $69.43 \pm 20.76 \mathrm{bc}$ \\
\hline 4 & $104.71 \pm 5.87 \mathrm{c}$ & $654.78 \pm 13.92 \mathrm{e}$ & $157.41 \pm 9.89^{a}$ & $69.55 \pm 5.97 \mathrm{~b}$ & $99.12 \pm 11.67 \mathrm{a}$ \\
\hline 5 & $165.73 \pm 8.17 \mathrm{a}$ & $761.09 \pm 8.64^{c}$ & $117.99 \pm 3.78 \mathrm{bc}$ & $54.46 \pm 2.78 \mathrm{~cd}$ & $64.23 \pm 9.49 \mathrm{bc}$ \\
\hline 6 & $102.39 \pm 6.32^{c}$ & $665.66 \pm 9.98 \mathrm{e}$ & $102.41 \pm 5.34^{c}$ & $57.23 \pm 4.41^{c}$ & $65.44 \pm 8.25$ bc \\
\hline 7 & $147.33 \pm 10.95^{b}$ & $946.75 \pm 12.26^{\mathrm{a}}$ & $120.66 \pm 20.59 \mathrm{~b}$ & $82.22 \pm 9.28{ }^{a}$ & $67.77 \pm 10.42 \mathrm{bc}$ \\
\hline 8 & $99.99 \pm 6.81^{c}$ & $848.76 \pm 10.80^{b}$ & $110.89 \pm 7.72 \mathrm{bc}$ & $63.96 \pm 8.27 \mathrm{bc}$ & $47.15 \pm 14.42^{c}$ \\
\hline Average & $123.04 \pm 24.05$ & $703.46 \pm 154.31$ & $162.39 \pm 24.20$ & $58.36 \pm 13.44$ & $68.68 \pm 14.60$ \\
\hline
\end{tabular}

Average value \pm standard deviation $(\mathrm{n}=3$ ). Romans' letters represent the significance of the difference (Duncan test, $\mathrm{p}<0.05)$. The difference between any two values, followed by at least one common letter, is insignificant. $\mathrm{LOQ}=$ lower than the limit of quantification. 
Table 6. Determination of trace elements found in soil from Dealu Bujorului vineyard by ICP-MS (mg/kg (mean \pm SD)

\begin{tabular}{|c|c|c|c|c|c|c|c|}
\hline Soil sample & & $\mathrm{Fe}$ & $\mathrm{Cu}$ & $\mathrm{Mn}$ & $\mathrm{Zn}$ & $\mathrm{Li}$ & $\mathrm{Cr}$ \\
\hline Normal values & & - & $20 \mathrm{mg} / \mathrm{kg}$ & $900 \mathrm{mg} / \mathrm{kg}$ & $100 \mathrm{mg} / \mathrm{kg}$ & - & $30 \mathrm{mg} / \mathrm{kg}$ \\
\hline \multirow{2}{*}{$\begin{array}{l}\text { Alert } \\
\text { threshold } \\
\end{array}$} & Susceptible & - & $100 \mathrm{mg} / \mathrm{kg}$ & $1500 \mathrm{mg} / \mathrm{kg}$ & $300 \mathrm{mg} / \mathrm{kg}$ & - & $100 \mathrm{mg} / \mathrm{kg}$ \\
\hline & Less susceptible & - & $250 \mathrm{mg} / \mathrm{kg}$ & $2000 \mathrm{mg} / \mathrm{kg}$ & $700 \mathrm{mg} / \mathrm{kg}$ & - & $300 \mathrm{mg} / \mathrm{kg}$ \\
\hline \multirow{2}{*}{$\begin{array}{l}\text { Intervention } \\
\text { threshold }\end{array}$} & Susceptible & - & $200 \mathrm{mg} / \mathrm{kg}$ & $2500 \mathrm{mg} / \mathrm{kg}$ & $600 \mathrm{mg} / \mathrm{kg}$ & - & $300 \mathrm{mg} / \mathrm{kg}$ \\
\hline & Less susceptible & - & $500 \mathrm{mg} / \mathrm{kg}$ & $4000 \mathrm{mg} / \mathrm{kg}$ & $1500 \mathrm{mg} / \mathrm{kg}$ & - & $600 \mathrm{mg} / \mathrm{kg}$ \\
\hline 1 & & $68.96 \pm 7.11^{\text {cd }}$ & $127.24 \pm 4.31^{\mathrm{a}}$ & $13.56 \pm 2.09 \mathrm{ab}$ & $5.99 \pm 2.02 \mathrm{ab}$ & $28.82 \pm 3.51^{\mathrm{c}}$ & $3.02 \pm 0.98^{\mathrm{d}}$ \\
\hline 2 & & $58.16 \pm 14.73^{d}$ & $56.63 \pm 1.71^{\mathrm{d}}$ & $15.72 \pm 3.66^{\mathrm{a}}$ & $6.72 \pm 0.38 \mathrm{ab}$ & $26.26 \pm 7.04^{\mathrm{cd}}$ & $2.72 \pm 1.01^{\mathrm{d}}$ \\
\hline 3 & & $101.18 \pm 3.46^{b}$ & $120.97 \pm 6.69 \mathrm{a}$ & $9.75 \pm 1.28$ bc & $7.72 \pm 1.99 \mathrm{a}$ & $50.19 \pm 2.67 \mathrm{~b}$ & $5.09 \pm 1.75$ bcd \\
\hline 4 & & $80.36 \pm 7.34^{c}$ & $102.26 \pm 3.25^{b}$ & $11.89 \pm 2.02 \mathrm{ab}$ & $6.45 \pm 0.96 \mathrm{ab}$ & $123.16 \pm 8.55^{a}$ & $7.45 \pm 2.03 \mathrm{ab}$ \\
\hline 5 & & $121.14 \pm 6.96^{\mathrm{a}}$ & $79.91 \pm 4.97^{\mathrm{c}}$ & $6.42 \pm 0.80^{\mathrm{c}}$ & $3.80 \pm 1.30^{\mathrm{b}}$ & $15.50 \pm 5.76^{\mathrm{e}}$ & $4.34 \pm 1.73 \mathrm{~cd}$ \\
\hline 6 & & $76.53 \pm 17.40 \mathrm{~cd}$ & $71.99 \pm 6.27^{c}$ & $9.26 \pm 2.53 \mathrm{bc}$ & $5.50 \pm 2.37 \mathrm{ab}$ & $20.16 \pm 1.73$ cde & $3.76 \pm 1.51 \mathrm{~cd}$ \\
\hline 7 & & $75.95 \pm 11.56^{\text {cd }}$ & $57.72 \pm 12.49^{d}$ & $14.84 \pm 3.98^{\mathrm{a}}$ & $6.39 \pm 1.86 \mathrm{ab}$ & $18.16 \pm 3.01 \mathrm{de}$ & $9.96 \pm 1.38^{a}$ \\
\hline 8 & & $65.02 \pm 9.36^{\mathrm{cd}}$ & $115.99 \pm 15.02 \mathrm{ab}$ & $5.28 \pm 1.96^{c}$ & $6.62 \pm 1.36 \mathrm{ab}$ & $52.48 \pm 3.78^{b}$ & $6.45 \pm 0.96 \mathrm{bc}$ \\
\hline Average & & $80.91 \pm 20.65$ & $91.59 \pm 28.62$ & $10.84 \pm 3.82$ & $6.15 \pm 1.14$ & $41.84 \pm 35.72$ & $5.35 \pm 2.47$ \\
\hline
\end{tabular}

Average value \pm standard deviation $(n=3)$. Roman letters represent the significance of the difference (Duncan test, $\mathrm{p}<0.05)$. The difference between any two values, followed by at least one common Average value \pm standard deviation $(\mathrm{n}=3)$. Roman letters represent the significance of the difference (Duncan test,

Table. 7. Determination of heavy elements found in soil from Dealu Bujorului vineyard by ICP-MS (mg/kg); (mean \pm SD)

\begin{tabular}{|c|c|c|c|c|c|c|c|}
\hline Soil sample & & $\mathrm{Cd}$ & $\mathrm{Pb}$ & Co & As & $\mathrm{Hg}$ & $\mathrm{U}$ \\
\hline Normal values & & $1 \mathrm{mg} / \mathrm{kg}$ & $20 \mathrm{mg} / \mathrm{kg}$ & $15 \mathrm{mg} / \mathrm{kg}$ & $5 \mathrm{mg} / \mathrm{kg}$ & $0.1 \mathrm{mg} / \mathrm{kg}$ & - \\
\hline \multirow{2}{*}{$\begin{array}{l}\text { Alert } \\
\text { threshold }\end{array}$} & Susceptible & $3 \mathrm{mg} / \mathrm{kg}$ & $50 \mathrm{mg} / \mathrm{kg}$ & $30 \mathrm{mg} / \mathrm{kg}$ & $15 \mathrm{mg} / \mathrm{kg}$ & $1 \mathrm{mg} / \mathrm{kg}$ & - \\
\hline & Less susceptible & $5 \mathrm{mg} / \mathrm{kg}$ & $250 \mathrm{mg} / \mathrm{kg}$ & $100 \mathrm{mg} / \mathrm{kg}$ & $25 \mathrm{mg} / \mathrm{kg}$ & $4 \mathrm{mg} / \mathrm{kg}$ & - \\
\hline \multirow{2}{*}{$\begin{array}{l}\text { Intervention } \\
\text { threshold }\end{array}$} & Susceptible & $5 \mathrm{mg} / \mathrm{kg}$ & $100 \mathrm{mg} / \mathrm{kg}$ & $50 \mathrm{mg} / \mathrm{kg}$ & $25 \mathrm{mg} / \mathrm{kg}$ & $2 \mathrm{mg} / \mathrm{kg}$ & - \\
\hline & Less susceptible & $10 \mathrm{mg} / \mathrm{kg}$ & $1000 \mathrm{mg} / \mathrm{kg}$ & $250 \mathrm{mg} / \mathrm{kg}$ & $50 \mathrm{mg} / \mathrm{kg}$ & $10 \mathrm{mg} / \mathrm{kg}$ & - \\
\hline 1 & & $0.18 \pm 0.05^{\mathrm{c}}$ & $8.89 \pm 0.59 \mathrm{a}$ & $21.35 \pm 2.54^{\mathrm{a}}$ & $0.92 \pm 0.06 \mathrm{bc}$ & $0.043 \pm 0.024 \mathrm{~b}$ & $0.60 \pm 0.13 \mathrm{a}$ \\
\hline 2 & & $0.25 \pm 0.08$ bc & $8.38 \pm 0.78^{a}$ & $17.12 \pm 3.53 \mathrm{ab}$ & $0.93 \pm 0.18 \mathrm{bc}$ & $0.075 \pm 0.028 \mathrm{ab}$ & $0.39 \pm 0.15 \mathrm{ab}$ \\
\hline 3 & & $0.20 \pm 0.05 \mathrm{bc}$ & $3.63 \pm 0.85^{\mathrm{c}}$ & $9.10 \pm 3.33^{c}$ & $0.77 \pm 0.13 \mathrm{bc}$ & $0.072 \pm 0.021$ ab & $0.58 \pm 0.17 \mathrm{a}$ \\
\hline 4 & & $0.35 \pm 0.09 \mathrm{ab}$ & $6.29 \pm 0.08^{b}$ & $18.49 \pm 0.95 \mathrm{ab}$ & $1.17 \pm 0.12 \mathrm{ab}$ & $0.076 \pm 0.022 \mathrm{ab}$ & $0.58 \pm 0.15^{a}$ \\
\hline 5 & & $0.28 \pm 0.08$ bc & $6.18 \pm 0.53^{b}$ & $13.77 \pm 1.73 \mathrm{bc}$ & $1.53 \pm 0.52^{\mathrm{a}}$ & $0.062 \pm 0.004 \mathrm{ab}$ & $0.29 \pm 0.04 \mathrm{~b}$ \\
\hline 6 & & $0.49 \pm 0.15^{\mathrm{a}}$ & $1.92 \pm 0.58^{\mathrm{d}}$ & $7.48 \pm 1.15^{\mathrm{c}}$ & $0.56 \pm 0.12^{\mathrm{c}}$ & $0.081 \pm 0.023 \mathrm{a}$ & $0.47 \pm 0.08 \mathrm{ab}$ \\
\hline 7 & & $0.26 \pm 0.06 \mathrm{bc}$ & $3.67 \pm 0.84^{\mathrm{c}}$ & $18.30 \pm 6.80 \mathrm{ab}$ & $0.82 \pm 0.24 \mathrm{bc}$ & $0.071 \pm 0.022 \mathrm{ab}$ & $0.39 \pm 0.05^{b}$ \\
\hline 8 & & $0.25 \pm 0.08 \mathrm{bc}$ & $6.29 \pm 1.37^{b}$ & $9.38 \pm 3.48^{\mathrm{c}}$ & $0.99 \pm 0.09 \mathrm{bc}$ & $0.093 \pm 0.007 \mathrm{a}$ & $0.59 \pm 0.12^{a}$ \\
\hline Average & & $0.28 \pm 0.10$ & $5.65 \pm 2.42$ & $14.37 \pm 5.20$ & $0.96 \pm 0.29$ & $0.070 \pm 0.015$ & $0.48 \pm 0.13$ \\
\hline
\end{tabular}


Manganese plays an essential role in living things, including humans, such as oxidative phosphorylation, fatty acid, and cholesterol metabolism, mucopolysaccharide metabolism, and activation of some enzymes (Prashanth et al., 2015). The concentration of $\mathrm{Mn}$ in wine depends on the uptake capacity of the vine as well as on the contribution of the soil. The amount of $\mathrm{Mn}$ in wines may also be influenced by agricultural practices and equipment of the cellar (Fabani et al., 2010, Geana et al., 2016). Mn concentration range from $0.11 \pm 0.02 \mathrm{mg} / \mathrm{L}$ to $0.63 \pm 0.12 \mathrm{mg} / \mathrm{L}$ (Table $3)$. The results agree with values reported in the literature in the wine produced in Turkey $(1.01 \mathrm{mg} / \mathrm{L} \mathrm{Mn}-1.94$ $\mathrm{mg} / \mathrm{L} \mathrm{Mn}$ ) (Karataș et al., 2015) and Romania, obtained at Dragașani and Recaș vineyards (0.16 mg/L Mn - 1.87 $\mathrm{mg} / \mathrm{L} \mathrm{Mn)} \mathrm{(Geana} \mathrm{et} \mathrm{al.,} \mathrm{2014).}$

Zinc is one of the essential elements required by the human system (Izah et al., 2016), it plays several functions in the human body, such as wound healing, blood clotting, proper thyroid function, maintenance of good vision (Chasapis et al., 2012, Izah et al., 2016, Salako et al., 2016), taste acuity, prostaglandin production, bone mineralization, cognitive functions, fetal growth, sperm production, cell growth, development, differentiation, homeostasis, connective tissue growth and maintenance, protein synthesis, DNA synthesis, RNA transcription, cell division, and cell activation (Chasapis et al., 2012, Izah et al., 2016, Marias et al., 2009). There is a limit for $\mathrm{Zn}$ concentration in wines, introduced in some countries due to health risk concerns. Specifically, Office International de la Vinge et du Vin recommends that the maximal concentration may not exceed $5 \mathrm{mg} / \mathrm{L} \mathrm{Zn}$ (O.I.V., 2016). The highest concentration was recorded by the wine obtained from the Feteasca neagră variety $(3.59 \pm 0.56 \mathrm{mg} / \mathrm{L} \mathrm{Zn}$ and $3.30 \pm 0.13 \mathrm{mg} / \mathrm{L} \mathrm{Zn}$ ), with an average value of $3.33 \pm 0.23 \mathrm{mg} / \mathrm{L} \mathrm{Zn}$, as you can see the values obtained were well below the maximum allowed values. Zn concentration was also present in amounts similar to previously published results (Karataș et al., 2015, Lara et al., 2005, Geana et al., 2014, Bora et al., 2016, Geana et al., 2016, Bora et al., 2019). Higher concentrations may result from the vineyard, equipment or prolonged maceration and may lead to unfavorable effects on the sensory proprieties of wine (Ibanez et al., 2008).

Lithium is a naturally occurring alkali metal, which living organisms ingest from dietary sources and which is also present in trace amounts in the human body. In much higher concentration, $\mathrm{Li}$ is effective as a medication for mania and mood swings including manic depressive disorders (Demling et al., 2001). Taking lithium long-term could have a prophylactic effect on this kind of change in bodily requirements (Demling et al., 2001). Li concentration in wines does not seem to be influenced by the production process, their presence is due to the vineyard soil composition and ability of the plant to absorb those (Szefer et al., 2007). The importance of $\mathrm{Li}$ determination in wine increased because Li can be employed for geographical classification of wines (Szefer et al., 2007). In most samples, the concentration varied in the range of $4.57 \pm 0.58 \mathrm{mg} / \mathrm{L}$ (registered in the wine obtained from the Feteasca regală variety) to $19.23 \pm 2.00 \mathrm{mg} / \mathrm{L}$ (in Sauvignon blanc variety) with an average of $12.47 \pm 1.49$ $\mathrm{mg} / \mathrm{L} \mathrm{Li}$. From the obtained results it can be observed that the white wine $(13.49 \pm 0.77 \mathrm{mg} / \mathrm{L} \mathrm{Li})$ has a higher concentration of $\mathrm{Li}$ in comparison with red wine $(10.83 \pm 0.56 \mathrm{mg} / \mathrm{L} \mathrm{Li})$. The results agree with values reported in the literature by Ivanova-Peropulos et al. (2016), Bora et al. (2016) and Bora et al. (2019).

Chromium is one of the toxic essential metals, it is harmful to humans when its concentration exceeds tolerable limits. It aids in the biosynthesis of glucose tolerance factor (Marias et al., 2009, Iwegbue et al., 2013), utilization of sugar protein and fats (Orisakwe et al., 2014), catabolism of fat and carbohydrates, and the maintenance of blood glucose, especially in diabetic patients (Salako et al., 2016). A high concentration of $\mathrm{Cr}$ was recorded in Aligoté (1.08 $\pm 0.01 \mathrm{mg} / \mathrm{L} \mathrm{Cr}-$ average value) and also in Muscat Ottonel $(1.09 \pm 0.20 \mathrm{mg} / \mathrm{L} \mathrm{Cr}-$ average value) variety. $\mathrm{Cr}$ concentration was also present in amounts similar to previously published results (Bora et al., 2016, Geana et al., 2016, Bora et al., 2019).

Cadmium is one of the toxic heavy metals to human tissues even at low concentration, is used in several industries and it also occurs naturally in the environment as the Earth crust. Authors have reported that nonalcoholic beverages usually have low Cd content i.g., within the permissible limits as reported by Adepoju-Bello et al. (2012), Engwa et al. (2015), Salako et al. (2016), Magomya et al. (2015) and higher concentration above maximal permissible limit (MPL limits) have been reported by Iweala et al. (2014) and Adegbola et al. (2015). There is a limit for $\mathrm{Cd}$ concentration in wines, introduced in some countries due to health risk concerns, the limit was set to the values of $0.01 \mathrm{mg} / \mathrm{L} \mathrm{Cd}$ by International Organisation of Vine and Wine (O.I.V., 2016). The high concentrations of Cd were recorded in the Băbească neagră $(0.48 \pm 0.12 \mu \mathrm{g} / \mathrm{L} \mathrm{Cd}, 0.40 \pm 0.06 \mu \mathrm{g} / \mathrm{L} \mathrm{Cd}, 0.26 \pm 0.07 \mu \mathrm{g} / \mathrm{L}$ Cd whit an average value of $0.38 \pm 0.03 \mu \mathrm{g} / \mathrm{L} \mathrm{Cd})$ and Aligoté variety $(0.26 \pm 0.06 \mu \mathrm{g} / \mathrm{L} \mathrm{Cd}, 0.36 \pm 0.12 \mu \mathrm{g} / \mathrm{L} \mathrm{Cd}, 0.33 \pm 0.05 \mu \mathrm{g} / \mathrm{L} \mathrm{Cd}$ whit an average value of $0.32 \pm 0.04 \mu \mathrm{g} / \mathrm{L} \mathrm{Cd}$ ) but the obtained values are below the maximum limit allowed. At the opposite pole, the lowest concentration was recorded by the Burgund Mare $(0.14 \pm 0.07 \mu \mathrm{g} / \mathrm{L} \mathrm{Cd}, 0.11 \pm 0.01 \mu \mathrm{g} / \mathrm{L}$ $\mathrm{Cd}, 0.12 \pm 0.01 \mu \mathrm{g} / \mathrm{L} \mathrm{Cd}$ whit an average value of $0.12 \pm 0.03 \mu \mathrm{g} / \mathrm{L} \mathrm{Cd})$ and Feteasca regală variety $(0.14 \pm 0.07 \mu \mathrm{g} / \mathrm{L}$ $\mathrm{Cd}, 0.12 \pm 0.02 \mu \mathrm{g} / \mathrm{L} \mathrm{Cd}, 0.14 \pm 0.05 \mu \mathrm{g} / \mathrm{L} \mathrm{Cd}$ whit an average value of $0.13 \pm 0.03 \mu \mathrm{g} / \mathrm{L}$ ) Cd. The results agree with values reported in the literature by Ivanova-Petropulos et al. (2013) $0.25 \mu \mathrm{g}$ Đurđic et al. (2017) Cd/L, $0.14 \mu \mathrm{g} / \mathrm{L}$ Cd, but compared with other results (Ivanova-Petropulos et al., 2013), the concentration of Cd was significantly higher than ours $10.60 \mu \mathrm{g} / \mathrm{L} \mathrm{Cd}$.

Lead is found in the Earth crust and has been reported to emit from anthropogenic activities, such as combustion of fossil fuels, mining, paint, battery production, etc. Pb was found above (MPL) limits in beverages (alcoholic and non-alcoholic), as reported by Engwa et al. (2015), Ogunlana et al. (2015), and low concentration by Adepoju-Bello et al. (2012), and Iweala et al. (2014). International Organisation of Vine and Wine (O.I.V.) set a maximum 
permissible limit for the concentration of $\mathrm{Pb}$ in wines due to health risk concerns, the limit was set to $0.15 \mathrm{mg} / \mathrm{L} \mathrm{Pb}$ (O.I.V., 2016). All wines had Pb concentration below $0.15 \mathrm{mg} / \mathrm{L}$ (mean value was $0.04 \mathrm{mg} / \mathrm{L}$ ), considered to be the minimum concentration necessary to endanger life. $\mathrm{Pb}$ concentration was also present in amounts similar to previously published results by Avram et al. (2014) and Đurđic et al. (2017).

The possibility of contamination of wine with toxic heavy metals has led to many attempts to improve winemaking technology. The increased use of stainless-steel winery equipment and machinery has resulted in an increased concentration of metals such as $\mathrm{Cr}, \mathrm{Co}, \mathrm{Ni}$, and V (Szefer et al., 2007). Co can also originate from the contact of wines with glass bottles if they are made from either nickel oxide or blue glass, which can contain up to 0.02-0.05 $\mathrm{mg} / \mathrm{L}$ Co (Szefer et al., 2007). Concentration of Co has recorded values between $1.51 \pm 0.71 \mu \mathrm{g} / \mathrm{L}, 1.43 \pm 0.59 \mu \mathrm{g} / \mathrm{L}$, $1.40 \pm 0.16 \mu \mathrm{g} / \mathrm{L}$ in the wine obtained from Băbească gri variety and $20.70 \pm 1.61 \mu \mathrm{g} / \mathrm{L}, 21.05 \pm 0.22 \mu \mathrm{g} / \mathrm{L}, 18.46 \pm$ $0.74 \mu \mathrm{g} / \mathrm{L}$ in Feteasca regală variety with an average value of $5.85 \pm 1.02 \mu \mathrm{g} / \mathrm{L}$ Co. The average values show that the white wines have higher Co level $(6.11 \mu \mathrm{g} / \mathrm{L} \mathrm{Co})$ then red wines $(5.45 \mu \mathrm{g} / \mathrm{L} \mathrm{Co})$.

The results agree with other studies in Macedonia 3.9 $\mu \mathrm{g} / \mathrm{L}$ Co (Ivanova-Petropulos et al., 2013) and 13.90 $\mu \mathrm{g} / \mathrm{L}$ Co (Ivanova-Petropulos et al., 2016), and in Serbia (Đurđic et al., 2017) 3.89 $\mu \mathrm{g} / \mathrm{L}$ Co for red wines and 3.96 $\mu \mathrm{g} / \mathrm{L}$ Co for white wines.

Arsenic is one of the non-essential heavy metals found in the environment, its concentration in ingestible items suggests contamination. Vines absorb arsenic from the soil in its most stable form of As (V) and about $60 \%$ of this amount is reduced during fermentation to the highly toxic trivalent state - As (III) (Szefer et al., 2007). The reduction of As (V) is followed by a 10 to $30 \%$ precipitation of $\mathrm{As}$ (III) as $\mathrm{As}_{2} \mathrm{~S}_{3}$ and the remaining amount stays dissolved in the wine (Szefer et al., 2007). When vineyards are treated with arsenic pesticides, the corresponding wines seem to have a relatively high concentration (up to $1 \mathrm{mg} / \mathrm{L}$ As) (Szefer et al., 2007). Office International de la Vinge et du Vin set a maximum permissible limit for the concentration of As in wines the limit of $0.2 \mathrm{mg} / \mathrm{L}$ As (O.I.V., 2016). All wines had As concentration below $0.2 \mathrm{mg} / \mathrm{L}$ (mean value was $0.009 \mathrm{mg} / \mathrm{L}$ ), considered to be the minimum concentration necessary to endanger life. The results agree with other studies in Serbia (Đurđic et al., 2017) 16.1 $\mu \mathrm{g} / \mathrm{L}$ As for red wines, and 9.46 $\mu \mathrm{g} / \mathrm{L}$ As for white wines, in Macedonia (Ivanova-Petropulos et al., 2016) 11.7 $\mu \mathrm{g} / \mathrm{L}$ As, in Romania (Avram et al., 2014) $21.12 \mu \mathrm{g} / \mathrm{L}$ As.

Mercury is a naturally occurring element that is present throughout the environment, being recognized as a global contaminant because it can undergo long-range transport in the atmosphere, persistent in the environment, accumulated in the food web, and pose severe adverse on the human and ecosystem health (Fizgerald et al., 2005). In the biological systems and the environment, $\mathrm{Hg}$ can exist in their oxidation states, namely, $\mathrm{Hg}(0)(\mathrm{metallic}), \mathrm{Hg}$ (II) (mercuric), and Hg (I) (mercurous), with the monovalent form being rare owing to its instability (Ullrich et al., 2001). All forms of $\mathrm{Hg}$ are toxic, but particularly problematic are the organic forms such as $\mathrm{MeHg}$, which is a neurotoxin (Clarkson and Magos, 2006). In addition to neurotoxicity, $\mathrm{Hg}$, in inorganic and/or organic forms, can affect other systems and sequentially cause adverse effects including renal toxicity, myocardial infarction, immune malfunction, and irregular blood pressure (Guangliang et al., 2012). Concentration of Hg has recorded values between $0.35 \pm 0.12 \mu \mathrm{g} / \mathrm{L}, 0.39 \pm 0.02 \mu \mathrm{g} / \mathrm{L}, 0.35 \pm 0.08 \mu \mathrm{g} / \mathrm{L}$ in the wine obtained from Fetească regală variety and $0.15 \pm 0.07 \mu \mathrm{g} / \mathrm{L}, 0.16 \pm 0.03 \mu \mathrm{g} / \mathrm{L}, 0.19 \pm 0.05 \mu \mathrm{g} / \mathrm{L}$ in Aligoté variety with an average value of $0.19 \pm 0.05 \mu \mathrm{g} / \mathrm{L} \mathrm{Hg}$ The average values show that the white wines have higher values $(0.21 \mu \mathrm{g} / \mathrm{L} \mathrm{Hg})$ compared to red wines $(0.16 \mu \mathrm{g} / \mathrm{L}$ $\mathrm{Hg}$ ). The results agree with those made in Romania (Avram et al., 2014) for Sauvignon Blanc 0.56 $\mu \mathrm{g} / \mathrm{L} \mathrm{Hg}$, Fetească alba $0.22 \mu \mathrm{g} / \mathrm{L} \mathrm{Hg}$ and Italian Riesling $0.16 \mu \mathrm{g} / \mathrm{L} \mathrm{Hg}$.

Uranium is a naturally occurring element and is quite abundant in seawater, freshwater sources, soil, and plants, consequently humans are continually exposed to U compounds mainly through their diet and less significant to Ucontaining aerosols through the air they breathe (Karpas, 2014). These nonessential elements are toxic at very low doses with a long biological half-life so that exposure to them is potentially harmful (Karpas, 2014). The kidney can absorb and accumulate divalent metal ions and is the first target organ of heavy metal toxicity (Barbier et al., 2005). The U concentration in the studied wine samples was relatively low, having an average of $0.18 \pm 0.04 \mu \mathrm{g} / \mathrm{L}$, higher concentration was recorded by white wine $(0.18 \mu \mathrm{g} / \mathrm{L} \mathrm{U})$ compared to red wine $(0.16 \mu \mathrm{g} / \mathrm{L} \mathrm{U})$. These results seem to be compatible with some other studies $0.11 \mu \mathrm{g} / \mathrm{L} \mathrm{U}$ (Ivanova-Petropulos et al., 2013), and was also present in amounts similar to previously published results (Bora et al., 2016, Bora et al., 2017, Bora et al., 2019).

Examining the factors which influenced the concentration of metals in wines, it can be seen that the content in $\mathrm{Ca}, \mathrm{K}, \mathrm{Na}, \mathrm{Mg}, \mathrm{P}, \mathrm{Fe}, \mathrm{Cu}, \mathrm{Mn}, \mathrm{Zn}, \mathrm{Li}, \mathrm{Cr}, \mathrm{Cd}, \mathrm{Pb}, \mathrm{Co}, \mathrm{As}, \mathrm{Hg}$, and $\mathrm{U}$ was significantly influenced by the variety factor.

Viticulture is an important agricultural practice in many countries and the long-term use of organic and inorganic pesticides in vineyards has led to increased concentration of these pollutants in soils and other environmental compartments (Flores-Vélez et al., 1996, Ribolzi et al., 2002, Solgi et al., 2016). Contamination with metals, heavy metals, together with erosion and tillage, reduces the quality of soils and poses serious environmental and toxicological threats. Vineyard soils are usually highly degraded soils in terms of biochemical properties (Miguéns et al., 2007), so they are more susceptible to contamination (Rodríguez Martín et al., 2007, Solgi et al., 2016). The natural concentration of metals and heavy metals in soils depends primarily on geological parent material composition, however, due to human activities, the heavy metal concentration in soils frequently rises (Solgi et al., 2016). Additionally, the mineral characterization of soils from Dealu Bujorului vineyard according to $\mathrm{Ca}, \mathrm{K}, \mathrm{Na}, \mathrm{Mg}, \mathrm{P}, \mathrm{Fe}, \mathrm{Cu}, \mathrm{Mn}, \mathrm{Zn}, \mathrm{Li}, \mathrm{Cr}, \mathrm{Cd}, \mathrm{Pb}, \mathrm{Co}, \mathrm{As}, \mathrm{Hg}$ and $\mathrm{U}$ was performed. The obtained results are described in 
Tables 5, 6 and 7. As expected, the highest concentration was obtained for $\mathrm{K}(703.46 \pm 154.31 \mathrm{mg} / \mathrm{kg}), \mathrm{Na}(162.39$ $\pm 24.20 \mathrm{mg} / \mathrm{kg})$, Ca $(123.04 \pm 24.05 \mathrm{mg} / \mathrm{kg}), \mathrm{Mg}(58.36 \pm 13.44 \mathrm{mg} / \mathrm{kg})$ and P $(68.68 \pm 14.60 \mathrm{mg} / \mathrm{kg})$. These minerals directly influence the growth and fruiting of wines, which may be the most likely from the fertilizers used in crop protection. Regarding the trace elements found in vineyard soil, these recorded average values between $91.59 \pm$ $28.62 \mathrm{mg} / \mathrm{kg}$ Cu to $5.35 \pm 2.47 \mathrm{mg} / \mathrm{kg} \mathrm{Cr}$, followed by $80.91 \pm 20.65 \mathrm{mg} / \mathrm{kg} \mathrm{Fe}, 41.84 \pm 35.72 \mathrm{mg} / \mathrm{kg} \mathrm{Li}, 10.84 \pm 3.82$ $\mathrm{mg} / \mathrm{kg} \mathrm{Mn}$ and $6.15 \pm 1.14 \mathrm{mg} / \mathrm{kg} \mathrm{Zn}$, as you can see the concentration of $\mathrm{Cu}$ in the vineyard soil exceeds the maximum limit allowed by the legislation $(20 \mathrm{mg} / \mathrm{kg} \mathrm{Cu}$ ) (O.I.V., 2016). Instead, the concentration of heavy metals in the soil was below the maximum limit allowed for the analyzed elements, Co recording the highest concentration (14.37 $\pm 5.20 \mathrm{mg} / \mathrm{kg}$ average value), following $\mathrm{Pb}(5.65 \pm 2.42 \mathrm{mg} / \mathrm{kg}$ average value) and As (0.96 $\pm 0.29 \mathrm{mg} / \mathrm{kg}$ average value).

The data demonstrate the light pollution of vineyard soil by copper. $\mathrm{Cu}$ concentration in the topsoil of Dealu Bujorului vineyard exceeds the maximum allowed limit $(20 \mathrm{mg} / \mathrm{kg})$, but the obtained values are much lower than those obtained by Mirlean et al. (2007) (between $1508.3 \mathrm{mg} / \mathrm{kg}$ to $2450.1 \mathrm{mg} / \mathrm{kg}$ ), these being the highest concentrations reported so far in the scientific literature on a vineyard soil. The $\mathrm{Cu}$ enrichment in different vineyard soil types reflects the period of copper-based pesticide application (Mirlean et al., 2007).

We expected to correlate the level of the elements in wine samples with the corresponding soil samples. This hypothesis was applied for $\mathrm{Ca}, \mathrm{K}, \mathrm{Na}, \mathrm{Mg}, \mathrm{P}, \mathrm{Fe}, \mathrm{Cu}, \mathrm{Mn}, \mathrm{Zn}, \mathrm{Li}, \mathrm{Cr}, \mathrm{Cd}, \mathrm{Pb}, \mathrm{Co}, \mathrm{As}, \mathrm{Hg}$ and $\mathrm{U}$. Even if the Cu concentration in soil exceeded the maximum limit allowed, in wine the $\mathrm{Cu}$ concentration was within normal limits.

The concentration of studied elements decreased with soil sampling depth which means that the surface soil area can be influenced by the environmental contaminants. According to the Romanian legislation (Order 756/1997), the metal concentration levels in studied soil samples show normal values for sensitive soil, except $\mathrm{Cu}$.

\section{CONCLUSIONS}

Generally, moderate wine consumption contributes to the daily nutritional requirements of many essential metals, including $\mathrm{Ca}, \mathrm{Mg}, \mathrm{K}, \mathrm{Na}, \mathrm{Fe}, \mathrm{Zn}, \mathrm{Mn}$ and $\mathrm{Cu}$. The high level of $\mathrm{Ca}, \mathrm{K}, \mathrm{Na}, \mathrm{Mg}, \mathrm{P}$ and $\mathrm{Fe}$ was observed in analyzed wine samples, the concentration of $\mathrm{Na}(60 \mathrm{mg} / \mathrm{L}), \mathrm{Cu}(1 \mathrm{mg} / \mathrm{L})$, As $(0.2 \mathrm{mg} / \mathrm{L}), \mathrm{Cd}(0.01 \mathrm{mg} / \mathrm{L}), \mathrm{Zn}(5 \mathrm{mg} / \mathrm{L})$ and Pb $(0.15$ $\mathrm{mg} / \mathrm{L}$ ) metals in analyzed wine samples were under Maximum Permissible Limits (MPL), respectively as published by the Organization of Vine and Wine. According to the results the highest concentration of $\mathrm{Ca}, \mathrm{K}, \mathrm{Na}, \mathrm{Mg}$ and $\mathrm{P}$ were found in Sauvignon blanc (101.92 $\pm 3.73 \mathrm{mg} / \mathrm{L} \mathrm{Ca})$, Cabernet Sauvignon (496.41 $\pm 6.20 \mathrm{mg} / \mathrm{L} \mathrm{K} ; 241.84 \pm 11.95$ $\mathrm{mg} / \mathrm{L} \mathrm{P}$ ), Feteasca neagră ( $47.00 \pm 6.35 \mathrm{mg} / \mathrm{L} \mathrm{Na}$ ), Muscat Ottonel (227.71 $\pm 4.16 \mathrm{mg} / \mathrm{kg} \mathrm{Mg}$ ). Fe is of importance to the winemaker because when it is present at $>7-10 \mathrm{mg} / \mathrm{L}$, it may cause cloudiness or colour change; all wines had Fe content over the $7 \mathrm{mg} / \mathrm{L}$ limit (mean value was $13.26 \pm 1.42 \mathrm{mg} / \mathrm{L} \mathrm{Fe}$ ) considered to be the minimum concentration necessary to form ferric cases. $\mathrm{Cu}$ concentration was within wide limits, Feteasca regala variety $(0.87$ $\pm 0.11 \mathrm{mg} / \mathrm{L})$ recorded the highest concentration and at the opposite pole was Băbeasca gri variety $(0.17 \pm 0.02$ $\mathrm{mg} / \mathrm{L}$ ) which recorded the lowest concentration, the average value of $\mathrm{Cu}$ concentration in wine was $0.52 \pm 0.12$ $\mathrm{mg} / \mathrm{L}$, a value that is significantly lower than the maximum permissible limit. The highest concentration of Zn was recorded by the wine obtained from the Feteasca neagră variety $(3.59 \pm 0.56 \mathrm{mg} / \mathrm{L}$ and $3.30 \pm 0.13 \mathrm{mg} / \mathrm{L})$, with an average value of $3.33 \pm 0.23 \mathrm{mg} / \mathrm{L}$, the values obtained were well below the maximum allowed values. The high concentrations of Cd were recorded in the Băbească neagră $(0.48 \pm 0.12 \mu \mathrm{g} / \mathrm{L}, 0.40 \pm 0.06 \mu \mathrm{g} / \mathrm{L}, 0.26 \pm 0.07 \mu \mathrm{g} / \mathrm{L}$ whit an average value of $0.38 \pm 0.03 \mu \mathrm{g} / \mathrm{L})$ and Aligoté variety $(0.26 \pm 0.06 \mu \mathrm{g} / \mathrm{L}, 0.36 \pm 0.12 \mu \mathrm{g} / \mathrm{L}, 0.33 \pm 0.05 \mu \mathrm{g} / \mathrm{L}$ whit an average value of $0.32 \pm 0.04 \mu \mathrm{g} / \mathrm{L}$ ) but the obtained values are below the maximum limit allowed. All wines had $\mathrm{Pb}$ concentration below $0.15 \mathrm{mg} / \mathrm{L}$ (mean value was $0.04 \mathrm{mg} / \mathrm{L}$ ), considered to be the minimum concentration necessary to endanger life. In the case of As all wine samples presented concentration below $0.2 \mathrm{mg} / \mathrm{L}$ (mean value was $0.009 \mathrm{mg} / \mathrm{L}$ ), considered to be the minimum concentration necessary to endanger life.

Examining the factors which influenced the concentration of metals in wines, it can be seen that the content in $\mathrm{Ca}, \mathrm{K}, \mathrm{Na}, \mathrm{Mg}, \mathrm{P}, \mathrm{Fe}, \mathrm{Cu}, \mathrm{Mn}, \mathrm{Zn}, \mathrm{Li}, \mathrm{Cr}, \mathrm{Cd}, \mathrm{Pb}, \mathrm{Co}, \mathrm{As}, \mathrm{Hg}$ and $\mathrm{U}$ was significantly influenced by the variety factor. In general, the values found are in line with previously reported data on wines from other origins.

Soil samples taken from vineyard locations showed similar results for the highest major mineral composition. Our results showed that the concentrations of the elements from wine and soil were interrelated. The average concentrations of elements in the soil decrease in the following order: $\mathrm{K}, \mathrm{Na}, \mathrm{Ca}, \mathrm{Cu}, \mathrm{Fe}, \mathrm{P}, \mathrm{Mg}, \mathrm{Li}, \mathrm{Co}, \mathrm{Mn}, \mathrm{Zn}, \mathrm{Pb}, \mathrm{Cr}$, As, $\mathrm{U}, \mathrm{Cd}$ and $\mathrm{Hg}$. The soil contained essential major elements for grapevine growth and the constituents of major elements in soils as affected by the composition of the soil conditions. The data demonstrate a light pollution of vineyard soil by copper. $\mathrm{Cu}$ concentration in the topsoil of the Dealu Bujorului vineyard exceeds the maximum allowed limit $(20 \mathrm{mg} / \mathrm{kg} \mathrm{Cu})$.

Author Contributions: B.F.D. Performed the analysis; B.F.D. Wrote the paper; A.C. Conceived and designed the analysis; C.I.B. Collected the data; V.R.F. Contributed data or analysis tools.

Funding Source: This research was funded by Ministry of Agriculture and Rural Development, project ADER no. 7.5.5. 


\section{Acknowledgments}

This paper was published under the frame of the Romanian Ministry of Agriculture and Rural Development, project ADER no. 7.5.5. „Research on the management of alcohol for the production of wine with a low alcohol content”.

\section{Conflicts of Interest}

The authors declare that they do not have any conflict of interest.

\section{REFERENCES}

1. Adegbola RA, Adekanmbi AI, Abiona DL, Atere AA (2015). Evaluation of some heavy metals contaminants in biscuits, fruit drinks, concentrates, candy, milk products and carbonated drinks sold in Ibana, Nigeria. International Journal of Biological and Chemical Sciences, 9(3): 1691-1696.

2. Adepoju-Bello AA, Oguntibeju O0, Onuegbu MT, Ayoola GAA, Coker HAB (2012). Analysis of selected metallic impurities in soft drinks marketed in Lagos, Nigeria. African Journal of Biotechnology, 11: 4676-4680.

3. Almeida CMR, Vasconcelos MTS (2003). Multielement composition of wines and their precursors including provenance soil and their potentialities as fingerprints of wine origin. Journal of Agricultural and Food Chemistry, 51: 4788-4798.

4. Avram V, Voica C, Hosu A, Cimpoiu C, Măruțoiu C (2014). ICP-MS characterization of some Romanian white wines by their mineral content. Revue Roumanine de Chimie, 59(11-12): 1009-1019.

5. Arvanitoyannis IS, Katsota MN, Psarra EP, Soufleros EH, Kallithraka K (1999). Application of quality control methods for assessing wine authenticity. Trends Food Science and Technology, 10: 321-336.

6. Álvarez M, Moreno IM, Jos Ă, Cameán AM, Gustavo González A (2007). Differentiation of two Andalusian DO „fino" wine according to their metal content from ICP-OES by using supervised pattern recognition methods. Microchemical Journal, 87(1): 72-76.

7. Álvarez M, Moreno IM, Pichardo S, Cameán AM, González AG (2012). Mineral profile of "fino" wines using inductively coupled plasma optical emission spectrometry methods. Food Chemistry, 135(1): 309-313.

8. Banović M, Kirin J, Ćurko N, Kovačević Ganić K (2009). Influence of vintage on $\mathrm{Cu}, \mathrm{Fe}, \mathrm{Zn}$ and $\mathrm{Pb}$ content in some Croatian red wines. Czech Journal of Food Sciences, 27: 401-403.

9. Barbier O, Jacquillet G, Tauc M, Cougnon M, Poujeol P (2005). Effect of heavy metals on, and handling by, the kidney. Nephron Physiology, 99(4): 105-110.

10. Bekker MZ, Day MP, Smith PA (2019). Changes in metal ion concentration in a Chardonnay wine related to oxygen exposure during vinification. Molecules. doi: https://doi.org/10.3390/molecules24081523

11. Bimpilas A, Tsimogiannis D, Balta-Brouma K, Lymperopoulou T, Orespoulou V (2015). Evolution of phenolic compounds and metal content of wine during alcoholic fermentation and storage. Food Chemistry, 178: 164171.

12. Bevin CJ, Dambergs RG, Fergusson AJ, Cozzolino D (2008). Varietal discrimination of Australian wines by means of mid-infrared spectroscopy and multivariate analysis. Analytica Chimica Acta, 621(1): 19-23.

13. Bora FD, Donici A, Oșlobanu A, Fițiu A, Babeș AC, Bunea CI (2016). Qualitative assessment of the white wine varieties grown in Dealu Bujorului vineyard, Romania. Notulae Botanicae Horti Agrobotanici Cluj-Napoca, 44(2): 593-602.

14. Bora FD, Donici A, Postolache E, Ciubucă A, Enache V, Tabaranu G, Bîrliga N, Racz I, Bunea CI (2017). Metal concentration of red wines in southeast Romania. Bulletin of UASVM Cluj-Napoca. Horticulture, 74(2): 129136.

15. Bora FD, Donici A, Rusu T, Bunea A, Popescu D, Bunea CI (2018). Elemental profile and ${ }^{207} \mathrm{~Pb} /{ }^{206} \mathrm{~Pb},{ }^{208} \mathrm{~Pb} /{ }^{206} \mathrm{~Pb}$, ${ }^{204} \mathrm{~Pb} /{ }^{206} \mathrm{~Pb},{ }^{87} \mathrm{Sr} /{ }^{86} \mathrm{~Pb}$ isotope ratio as fingerprints for geographical traceability of Romanian wines. Notulae Botanicae Horti Agrototanici Cluj-Napoca, 46(1): 223-239.

16. Bora FD, Călugăr A, Bunea CI, Racz I (2019). Assessment of trace elements and human health risk present in wines obtained in the region of Dealurile Munteniei and Dealurile Moldovei vineyard. Bulletin of UASVM ClujNapoca. Horticulture, 76(2): 164-178.

17. Bora FD, Bunea CI, Călugăr AM, Donici A (2019). Phenolic, anthocyanin composition and color measurent at red wines from Dealu Bujorului vineyard. Agricultura, 1-2: 14-28.

18. Bora FD, Bunea CI, Chira R, Bunea A (2020). Assessment of the quality of polluted areas in northwest Romania based on the content of elements in different organs of grapevine (Vitis vinifera). Molecules. Doi: $10.3390 /$ molecules25030750.

19. Castiñeira Gómez MDM, Brandt R, Jakubowski N, Andersson JT (2004). Classification of German white wines with certified brand of origin by multielement quantitation and pattern recognition techniques. Journal of Agricultural and Food Chemistry, 52: 2953-2974.

20. Chasapis CT, Loutsidou AC, Spiliopoulou CA, Stefanidou ME (2012). Zinc and human health: An update. Archives of Toxicology, 86(4): 521-534. 
21. Clarkson TW, Magos L (2006). The toxicology of mercury and its chemical compounds. Critical Reviews in Toxicology, 36(8): 609-662.

22. Cazzolino D, Kwiatkowski MJ, Dambergs RG, Cynkar WU, Janik LJ, Skouroumounis G, Gishen M (2008). Analysis of elements in wine using near infrared spectroscopy and partial least squares regression. Talanta, 74: 711716.

23. Cheng J, Liang C (2012). The variation of mineral profiles from grape juice to monovarietal Cabernet Sauvignon wine in the vinification process. Journal of Food Processing and Preservation, 36(3): 262-266.

24. Coetzee PP, van Jaarsveld FP, Vanhaecke F (2014). Intraregional classification of wine via ICP-MS elemental fingerprinting. Food Chemistry, 164: 485-492.

25. Dalipi R, Borgese L, Zacco A, Tsuji K, Sangiorgi E, Piro R, Bontempi E, Depero LE (2015). Determination of trace elements in Italian wine by means of total reflection X-ray fluorescence spectroscopy. International Journal of Environmental Analytical Chemistry, 95(1): 1-11.

26. Day MP, Zhang BL, Martin GJ (1994). The use of trace element data to complement stable isotope methods in the characterization of grape musts. American Journal of Enology and Viticulture, 45: 79-85.

27. Dehelean A, Voica C (2012). Determination of lead and strontium isotope ratios in wines by inductively coupled plasma mass spectrometry. Romanian Journal of Physics, 57(7-8): 1194-1203.

28. Demling JH, Eglau MC, Autenrieth T (2001). On the physiological function of lithium from a psychiatric view point. Medical Hypotheses, 57(4): 506-509.

29. De Villiers A, Alberts P., Tredoux AG, Nieuwoudt HH (2012). Analytical techniques for wine analysis: An African perspective; a review. Analytica Chimica Acta, 730: 2-23.

30. Đurđic S, Pantelic M, Trifkovic J, Vukokevic V, Natic M, Tesica Z, Mutic J (2017). Elemental composition as a tool for the assessment of type, seasonal variability, and geographical origin of wine and its contribution to daily elemental intake. RSC Advances, 7(4): 2151-2162.

31. Engwa AG, Ihekwoaba CJ, Ilo US, Unaegbu M, Ayuk I, Osuji AG (2015). Determination of some soft drink constituents and contamination by some heavy metals in Nigeria. Toxicology Reports, 2: 384-390.

32. Fabani MP, Arrúa RC, Vázquez F, Diaz MP, Baroni MV, Wunderlin DA (2010). Evaluation of elements profile coupled to chemometrics to assess the geographical origin of Argentinean wines. Food Chemistry, 119(1): 372379.

33. Frías S, Pérez Trujillo JP, Peña EM, Conde JE (2001). Classification and differentiation of bottled sweet of Canary Islands (Spain) by their metallic content. European Food Research and Technology, 213: 145-149.

34. Fitzgerald WF, Engstrom DR, Lamborg CH, Tseng CM, Balcom PH, Hammerschmidt CR (2005). Modern and historic atmospheric mercury fluxes in northern Alaska: global sources and arctic depletion. Environmental Science \& Technology, 39: 557-568.

35. Flores-Vélez LM, Ducaroir J, Jaunet AM, Robert M (1996). Study of the distribution of copper in an acid sandy vineyard soil by three different methods. European Journal of Soil Science, 47: 523-532.

36. Fraige K, Pereira-Filho ER, Carrilho E (2014). Fingerprinting of anthocyanins from grapes produced in Brazil using HPLC-DAD-MS and exploratory analysis by principal component analysis. Food Chemistry, 54(2): 18441858.

37. Geana I, Iordache A, Ionete R, Marinescu A, Ranca U, Culea M (2013). Geographical origin identification of Romanian wines by ICP-MS elements analysis. Food Chemistry, 138: 1125-1134.

38. Geana EI, Marinescu A, Iordache AM, Sandru C, Ionete RE, Bala C (2014). Differentiation of Romanian wines on geographical origin and wine variety by elemental composition and phenolic components. Food Analytical Methods, 7(10): 2064-2074.

39. Geana EI, Sandru C, Stanciu V, Ionete RE (2016). Elemental profile and ${ }^{87} \mathrm{Sr} /{ }^{86} \mathrm{Sr}$ isotope ratios as fingerprints for geographical traceability of wine an approach on Romanian wines. Food Analytical Methods, 10(1): 63-73.

40. Galgano F, Favati F, Caruso M, Scarpa T, Palma A (2008). Analysis of trace elements in southern Italian wines and their classification according to provenance. Food Science and Technology, 41: 1808-1815.

41. Giaccio M, Vicentini A (2008). Determination of the geographical origin of wines by means of the mineral content and the stable isotope ratios: a review. Journal of Commodity Science, Technology and Quality, 47(IIV): 267-284.

42. Grindaly G, Mora J, Gras L, Loos-Vollebregt MTC (2011). Atomic spectrometry methods for wine analysis: Acritical evaluation and discussion of recent applications. Analytica Chimica Acta, 691: 8-32.

43. Gonzálvez A, Llorens A, Cervera ML, Armenta S, De La Guardia M (2009). Elemental fingerprint of wines from the protected designation of origin Valencia. Food Chemistry, 112: 26c34.

44. Galani-Nikolakaki S, Kallithrankas-Kontos N, Katsanos A (2002). Trace element analysis of Cretan wine and wine products. Science of the Total Environment, 285: 155-163.

45. Godelmann R, Fang F, Humpfer E, Schüfer H, Spraul M (2013). Targeted and nontargeted wine analysis by NMR spectroscopy combined with multivariate statistical analysis. Differentiation of important parameters: grape variety, geographical origin, year of vintage. Journal of Agricultural and Food Chemistry, 61(23): 5610-5619.

46. Guangliang L, O’Driscoll N (2012). Chemistry and toxicology of mercury. (1th ed.). New Jersey: A John Wile \& Sons INC, (Chapter 1). 
47. Hopfer H, Nelson J, Mitchell AE, Heymann H, Ebeler SE (2013). Profiling the trace metal composition of wine as a function of storage temperature and packaging type. Journal of Analytical Atomic Spectrometry 28(8): 12881291.

48. Iglesias M, Besalú E, Anticó E (2007). Internal standardization-atomic spectrometry and geographical pattern recognition techniques for the multielement analysis and classification of Catalonian red wines. Journal of Agricultural and Food Chemistry, 55(2): 219-225.

49. Izah SC, Chakrabarty N, Srivastav AL (2016). A review on heavy metals concentration in potable water sources in Nigeria: human health effects and mitigating measures. Exposure and Health, 8: 285-304.

50. Izah SC, Inyang IR, Angaye TCN, Okawa IP (2017). A review of health metal concentration and potential health implication of beverages consumed in Nigeria. Toxic. Doi:10.3390/toxics5010001.

51. Ibanez JG, Carreon-Alvarez A, Barcena-Soto M, Casillas N (2008). Metals in alcoholic beverages: a review of sources, effects, concentrations, removal, speciation and analysis. Journal of Food Composition and Analysis, 21: 672-683.

52. Iwegbue CMA, Nwozo SO, Overah CI, Nwajei GE (2013). Concentrations of selected metals in some ready-toeat-foods consumed in southern Nigeria: estimation of dietary intakes and target hazard quotients. Turkish Journal of Agriculture - Food Science and Technology, 1(1): 1-7.

53. Iweala EEJ, Olugbuyiro JAO, Durodola BM, Fubara-Manuel DR, Okoli AO (2014). Metal contamination of foods and drinks consumed in Ota, Nigeria. Research Journal of Environmental Toxicology, 8(2): 92-97.

54. Ivanova-Petropulos V, Witsche H, Stafilov T, Stefova M, Motter H, Lankmayr E (2013). Multi-element analysis of Macedonian wines by inductively coupled plasma-mass spectrometry (ICP-MS) and inductively coupled plasma-optical emission spectrometry (IP-OES) for regional classification. Macedonian Journal of Chemistry and Chemical Engineering, 32(2): 265-281.

55. Ivanova-Petropulos V, Balabanova B, Mitrev S, Nedelkovski D, Dimovska V, Gulaboski R (2016). Optimization and validation of a microwave digestion method for multi-element characterization of Vranec wines. Food Analytical Methods, 9(1): 48-60.

56. Karataș Değirmenci D, Aydin F, Aydin I, Karataș H (2015). Elemental composition of red wines in southeast Turkey. Czech Journal of Food Sciences, 33: 228-236.

57. Kment P, Mihaljević M, Ettler V, Šebek O, Rohlová L (2005). Differentiation of Czech wines using multielement composition - A comparison with vineyard soil. Food Chemistry, 91(1): 157-165.

58. Karpas Z (2014). Analytical chemistry of uranium: environmental, forensic, nuclear, and toxicological applications. (1th ed.). New York: CRC Press, (Chapter 4).

59. Korenovska M, Suhaj M (2005). Identification of some Slovakian and European wines origin by the use of factor analysis of elemental data. European Food Research and Technology, 221: 550-558.

60. Lara R, Cerutti S, Salonia JA, Olsina RA, Martinez LD (2005). Trace element determination of Argentine wine using ETAAS and USN-ICP-OES. Food and Chemical Toxicology, 43(2): 293-297.

61. Lazos ES, Alexakis A (1989). Metal ion content of some Greek wines. International Journal of Food Science \& Technology, 24(1): 39-46.

62. Magomya AM, Yebpella GG, Okpaegbe UC (2015). An assessment of metal contamination levels in selected soft drinks sold in Nigeria. International Journal of Innovative Sciences, Engineering \& Technology, 2(10): 517-522.

63. Miguéns T, Leirós C, Gil-Sores F, Trasar-Cepeda C (2007). Biochemical properties of vineyard soils in Galicia, Spain. Science of the Total Environment 378: 218-222.

64. Marias AD, Blackhurst DM (2009). Do heavy metal counter the potential health benefits of wine? Journal of Endocrinology, Metabolism and Diabetes of South Africa, 14(2): 77-79.

65. Mirlean N, Roisenberg A, Chies JO (2007). Metal contamination of vineyard soil in wet subtropics (southern Brazil). Environmental Pollution, 149: 10-17.

66. Nelson J, Hopfer H, Gilleland G, Cuthbertson D, Boulton R, Ebeler SE (2015). Elemental profiling of Malbec wines under controlled conditions using microwave plasma-atomic emission spectroscopy. American Journal of Enology and Viticulture, 66: 373-378.

67. Nicolini G, Larcher R (2003). Evidence of changes in the micro-element composition of wine due to the yeast strain. Rivista di Viticoltura e di Enologia, 56: 45-48.

68. Núñez M, Peña RM, Herrero C, García-Martín S (2000). Analysis of some metals in wine by means of capillary electrophoresis. Application to the differentiation of Ribeira Sacra Spanish red wine. Analysis, 28: 432-437.

69. O.I.V. (2016). Maximum acceptable limits of various substances contained in wine. In Compendium of international methods of analysis of wine and must analysis. Paris, France.

70. Orisakwe OF, Ajaezi GC (2014). Heavy metal hazards of functional beverages in Nigeria. Malaysian Journal of Nutrition, 20: 121-131.

71. Ogunlana OO, Ogunlana OE, Akinsanya AE, Ologbenia OO (2015). Heavy metals toxicity and environment. Journal of Global Biosciences, 4(2): 1335-1338.

72. Paleologos EK, Giokas DL, Tzouwara-Karayanni SM, Karayannis MI (2002). Micelle mediated methodology for the determination of free and bound iron in wines by flame atomic absorption spectrometry. Analytica Chimica Acta, 458(1): 241-248. 
73. Pohl P. (2007). What do metals tell us about wine? Trends in Analytical Chemistry, 26(9): 941-949.

74. Prashanth L, Kattapagari KK, Chitturi RT, Baddam VRR, Prasad LK (2015). A review on role of essential trace elements in health and disease. Journal of NTR University of Health Sciences, 4(2): 75-85.

75. Paneque P, Morales ML, Burgos P, Ponce L, Callejón RM (2017). Elemental characterization of Andalusian wine vinegars with protected designation of origin by ICP-MS and chemometric approach. Food Chemistry, 75: 203210.

76. Płotka-Wasylka J, Frankowski M, Simeonov V, Polkowska Ż (2018). Determination of metals content in wine samples by inductively plasma-mass spectrometry. Molecules. Doi: $10.3390 /$ molecules 23112886.

77. Ražić S, Onjia A (2010). Trace element analysis and pattern recognition techniques in classification of wine from Central Balkan Countries. American Journal of Enology and Viticulture, 61(4): 506-511.

78. Ribolzi O, Valles V, Gomez L, Voltz M (2002). Speciation and origin of particulate copper in runoff water from a Mediterranean vineyard catchment. Environmental Pollution 117: 261-271.

79. Rodríguez Martín J, Vázguez CA, Grau Corbí J, López AM (2007). Factors controlling the spatial variability of copper in topsoils of the northeastern region of the Iberian Peninsula, Spain. Water, Air, and Soil Pollution, 186: 311-321.

80. Rodriguez Mozaz S, Garcia Sotro S, Garrido Segovia J, Ancin Azpilicueta C (1999). Influence of decantation of viura must on cation content. Evolution during wine fermentation and stabilization. Food Research International, 32(10): 683-689.

81. Salako SG, Adekoyeni OO, Adegbite AA, Hammed TB (2016). Determination of metals content of alcoholic and non-alcoholic canned drinks consumed at Idiroko border town Ogun State Nigeria. British Journal of Applied Science \& Technology, 12: 1-8.

82. Stępień AE, Stawarczyk K, Bilek M, Kędziora KM (2015). Analysis of selected chemical parameters in Piemontese Wines. Roczniki Państwowego Zakładu Higieny, 66(3): 217-223.

83. Szefer P, Nriagu JO (2007). Mineral components in foods. (1th ed.). New York: CRC Press, (Chapter 8).

84. Sass-Kiss A, Kiss J, Havadi B, Adanyi N (2008). Multivariate statistical analysis of botrytized wines of different origin. Food Chemistry, 110: 742-750.

85. Solgi E, Solgi M, Martín JAR (2016). Spatial variability of heavy metals concentrations in vineyard soils on Malayer Plains (Iran). Environmental Forensics, 17(1): 87-96.

86. Suhaj M, Korenovska M (2005). Application of elemental analysis for identification of wine origin. A review. Acta Alimentaria, 34(4): 393-401.

87. Stroh A, Brückner P, Vollkopf U (1994). Multielement analysis of wine sample using ICP-MS. Atomic Spectroscopy, 15: 100-106.

88. Šelih VS, Šala M, Drgan V (2014). Multi-element analysis of wines by ICP-MS and ICP-OES and their classification according to geographical origin in Slovenia. Food Chemistry, 153: 414-423.

89. Šperková J, Suchánek M (2005). Multivariate classification of wines from different Bohemian regions (Czech Republic). Food Chemistry, 93(4): 659-663.

90. Tariba B (2011). Metals in wine - impact on wine quality and health outcomes. Biological Trace Element Research 144(1-3): 143-156.

91. Thiel G, Geisler G, Blechschmidt I, Danzer K (2004). Determination of trace elements in wines and classification according to their provenance. Analytical and Bioanalytical Chemistry, 378: 1630-1636.

92. Țârdea C (2007). Chemistry and analysis of wine. (1th ed.). Iași: "Ion Ionescu de la Brad", (Chapter 14).

93. Ullrich SM, Tanton TW, Abdrashitova SA (2001). Mercury in the aquatic environment: a review of factors affecting methylation. Critical Review in Environmental Science and Technology, 31: 241-293.

94. Van Der Linde G, Fisher JL, Coetzee PP (2010). Multi-element analysis of classification according to geographical origin using multivariate statistics. European Food Research and Technology 31(2): 143-153.

95. Volpe MG, La Cara F, Volpe F, De Mattia A, Petitto F, Di Stasio M, Serino V (2009). Heavy metals uptake in the enological food chain. Food Chemistry, 117: 553-560.

96. Vrček IV, Bojić M, Žuntar I, Mendać-Šaric M (2011). Phenol content, antioxidant activity and metal composition of Croatian wines deriving from organically and conventionally grown grapes. Food Chemistry, 124(1): 354361.

97. Watson RR, Preedy VR (2004). Reviews in food and nutrition toxicity. (1th ed.). London: Taylor \& Francis, (Chapter 3).

98. Weldegergis BT, de Villiers A, Crouch A (2011). Chemometric investigation of the volatile content of young South African wines. Food Chemistry, 128(4): 1100-1109.

99. Zinicovscaia I, Duliu OG, Culiov OA, Sturza R, Bilici C, Gundorina S (2017). Geographical origin identification of Moldavian wines by neutron activation analysis. Food Analytical Methods, 10: 3523-3530. 